\title{
Stereoselective Synthesis and Structural Confirmation of the Specialized Pro-Resolving Mediator Resolvin E4
}

\author{
Amalie Føreid Reinertsen, ${ }^{\S}$ Karoline Gangestad Primdahl, ${ }^{\S}$ Ashley Elizabeth Shay, \\ Charles Nicholas Serhan, Trond Vidar Hansen, and Marius Aursnes*, ${ }^{*}$
}

Cite This: J. Org. Chem. 2021, 86, 3535-3545

Read Online

\section{ACCESS \\ 山lll Metrics \& More \\ | 回 Article Recommendations \\ Supporting Information}

ABSTRACT: Herein, we report the stereoselective and convergent synthesis of resolvin E4, a newly identified specialized proresolving mediator. This synthesis proves the absolute configuration and exact olefin geometry. Key elements of the successful strategy include a highly stereoselective MacMillan organocatalytic oxyamination, a Midland Alpine borane reduction, and the use of a 1,4-pentadiyne unit as a linchpin building block. The application of reaction telescoping in several of the synthetic transformations enabled the preparation of the resolvin E4 methyl ester in 10\% yield over 10 steps (longest linear sequence). The physical property (UV-Vis and LC-MS/MS) data of synthetic resolvin E4 matched those obtained from biologically produced material.

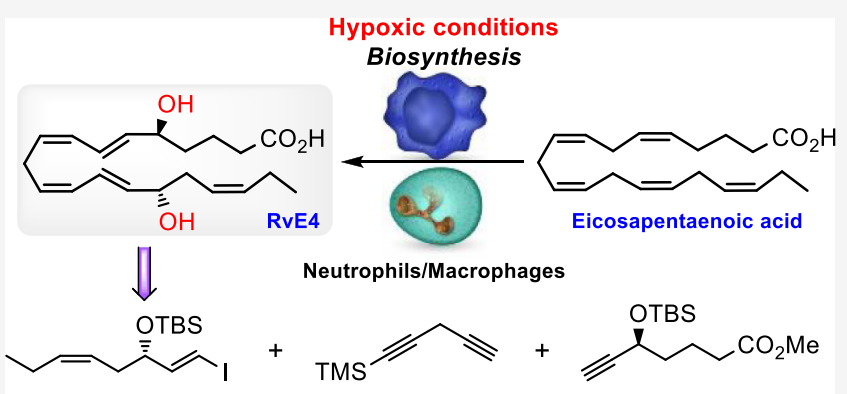

Ospecialized pro-resolving mediator resolvin E4

Synthetic and biogenic material sucessfully matched - structural confirmation

\section{INTRODUCTION}

Inflammation is a consequence of the immune system responding to injurious stimuli and constitutes an essential, protective strategy with the aim of restoring cellular homeostasis. Recent efforts concerning the mechanisms involved in the resolution of acute inflammation have provided evidence for a new superfamily of endogenous lipid mediators named specialized pro-resolving mediators (SPMs). ${ }^{1}$ These oxygenated polyunsaturated fatty acids are biosynthesized in the presence of lipoxygenase and cyclooxygenase enzymes. ${ }^{2}$ SPMs are chemically labile molecules formed in nano- to picogram amounts in vivo ${ }^{3}$ and exhibit anti-inflammatory and proresolving bioactions, often in the low nano- to picomolar range. ${ }^{2,3}$ Additionally, SPMs are important in the process of clearing bacterial infections and participate in host defense, organ protection, pain reduction and also play a role in tissue remodeling. ${ }^{3}$ The E-series resolvins, derived from eicosapentaenoic acid (EPA), were among the first SPMs to be reported (Figure 1). 4

RvE1 and RvE2 have been subjected to clinical trial development programs ${ }^{5}$ as well as drug discovery efforts with the aim of establishing new pro-resolution agonists. ${ }^{6}$ The active resolution processes governed by SPMs are considered a biomedical paradigm shift.

In 2019, Serhan and co-workers reported a new SPM and named it resolvin E4 (RvE4) based on its potent physiologic actions. ${ }^{8}$ This SPM is produced by human macrophages and neutrophils during physiologic hypoxic conditions $\left(1-5 \% \mathrm{O}_{2}\right)$. In contrast to the three earlier reported E-series resolvins, this SPM is formed after two consecutive lipoxygenation reactions

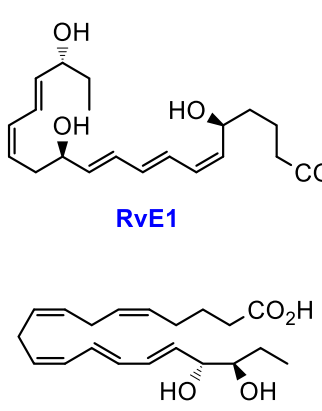

RvE3
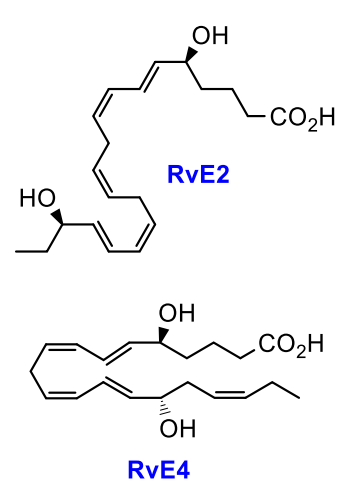

Figure 1. Reported E-series resolvins biosynthesized from EPA.

(Scheme 1). ${ }^{8}$ Earlier, $18 S$-configured epimers of RvE1, RvE2, and RvE3 have been identified. ${ }^{9}$ In the first step of the biosynthesis of $\mathrm{RvE} 4,15 S-\mathrm{H} p \mathrm{EPE}$ is formed by $15-\mathrm{LOX}$, while the second lipoxygenation step is catalyzed by 5-LOX. Reductions of the hydroperoxide intermediates $15 S-\mathrm{H} p \mathrm{EPE}$ and $5 S-\mathrm{H} p \mathrm{EPE}$ are facilitated by peroxidase activity (Scheme 1).

Received: December 9, 2020

Published: February 3, 2021 


\section{Scheme 1. Proposed Biosynthetic Pathway for RvE4}

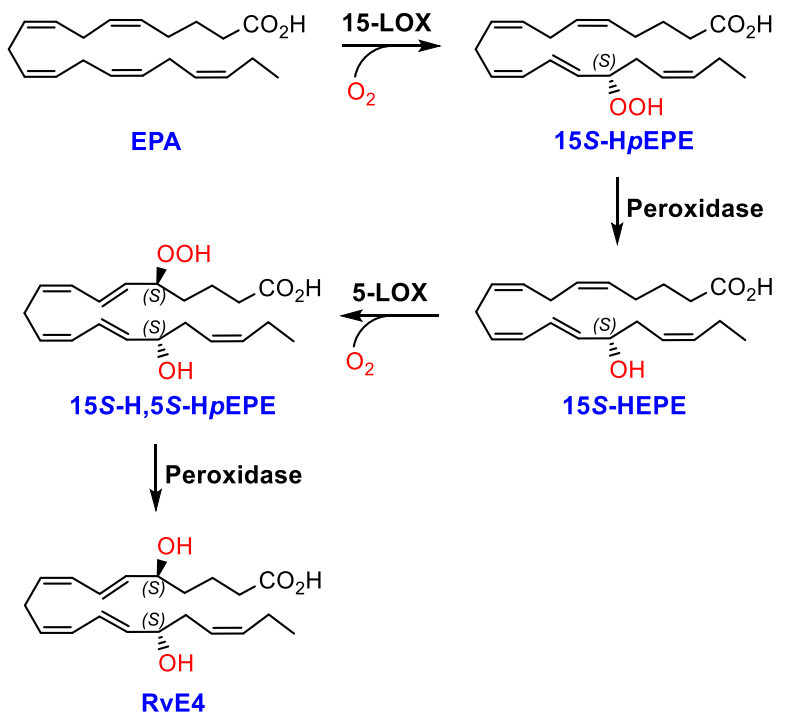

The need for absolute configuration assignments and materials of high chemical purity for further biological investigations and targeted lipidomic analyses has spurred great interest in the synthesis of the E-series resolvins. ${ }^{9 a, 10,11}$ Herein, we report the total synthesis of RvE4 (1) together with results from LC-MS/MS matching experiments that established its structure as $(5 S, 6 E, 8 Z, 11 Z, 13 E, 15 S, 17 Z)-5,15$ dihydroxyicosa-6,8,11,13,17-pentaenoic acid.

\section{RESULTS AND DISCUSSION}

An overview of the retrosynthetic analysis applied to the tentatively assigned structure of RvE4 (1) is shown in Scheme 2. The observation of a central $(Z, Z)-1,4$-pentadiene structural motif contained within the $\mathrm{C}_{2}$-symmetric $\mathrm{C} 4-\mathrm{C} 16$-domain of the molecule resulted in the first two disconnections being based on the Sonogashira cross-coupling reaction ${ }^{12}$ followed by $Z$-selective hydrogenation. This analysis identified three key fragments 3, 5, and 1-trimethylsilyl-1,4-pentadiyne (4), the latter serving the role of a linchpin, to be convergently assembled in the synthesis.

Fragment 3 was disconnected back to cis-4-heptenal (6) with an enantioselective, organocatalytic oxyamination ${ }^{13}$ as well as a Takai olefination ${ }^{14}$ planned as the two pivotal steps in the forward direction. The Carreira alkynylation was chosen as the key transformation for furnishing fragment $\mathbf{5}$, with the intent of later transforming the acetylene moiety into the corresponding E-vinyl halide functionality needed for the planned palladium cross-coupling chemistry.
Scheme 2. Overview of the Key Retrosynthetic Disconnections Made for RvE4 (1)
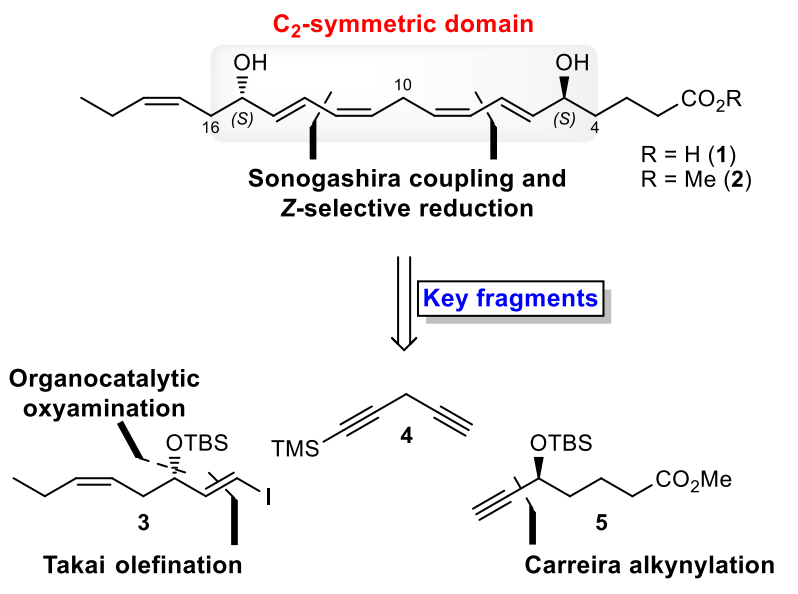

The project commenced with the construction of $\omega-3$ fragment 3 , starting from commercially available and affordable cis-4-heptenal (6). To this end, different $\alpha$-oxidation protocols were first examined based on literature protocols (Table 1).

In light of these results, we settled on an enantioselective, organocatalytic $\alpha$-oxyamination using $10 \mathrm{~mol} \% \mathrm{D}$-proline and nitrosobenzene in $\mathrm{CHCl}_{3}$ based on the procedure developed by the MacMillan group. ${ }^{13 \mathrm{~d}} \mathrm{~A}$ solvent switch to ethanol preceded the $\mathrm{NaBH}_{4}$-based reduction of the in situ masked aldehyde functionality, and then the comparatively weak $\mathrm{O}-\mathrm{N}$ bond was cleaved using zinc and acetic acid. After this sequence, a chromatographic purification step was introduced. The overall yield obtained for the described synthetic sequence was $80 \%$, and chiral HPLC analysis of the $\alpha$-aminoxylated alcohol intermediate 21 before zinc reduction to 7 showed an enantiomeric excess of $98 \%$ (Supporting Information).

The next objective was the regioselective TBS-protection of the secondary alcohol present in the 1,2-diol system in 7, and this was achieved by first masking the primary alcohol as the corresponding bulky pivaloyl ester and then adding a catalytic amount of 4-dimethylaminopyridine (DMAP) together with an excess of TBS triflate to the reaction mixture, yielding bisprotected 8 in $81 \%$ after column chromatography. A DIBAL-H reduction then cleanly did away with the pivaloyl moiety, and the primary alcohol was obtained in a crude form after work up and removal of volatiles under high-vacuum. This material was directly subjected to a Dess-Martin oxidation ${ }^{15}$ to give the corresponding aldehyde. Passing the crude material through a short plug of silica gel to remove periodinane-related residues was found beneficial before the next reaction. Finally, the vinyl

Table 1. Different Protocols Examined for the Organocatalytic Oxyamination of cis-4-Heptenal (6)

\begin{tabular}{|c|c|c|c|c|c|c|}
\hline Catalyst & Mol\% & Electrophile & Solvent & Temperature & Yield & Reference \\
\hline 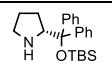 & 20 & & THF & $25^{\circ} \mathrm{C}$ & $42 \%$ & $13 a$ \\
\hline & 2 & & $\mathrm{MeCN}$ & $0^{\circ} \mathrm{C}$ & $20 \%$ & $13 b$ \\
\hline${ }_{\mathrm{H}} \cdot{ }^{\prime} \mathrm{CO}_{2} \mathrm{H}$ & 20 & & DMSO & $25^{\circ} \mathrm{C}$ & $31 \%$ & $13 \mathrm{c}$ \\
\hline & 10 & & $\mathrm{CHCl}_{3}$ & $0^{\circ} \mathrm{C}$ & $80 \%$ & $13 \mathrm{~d}, \mathrm{e}$ \\
\hline
\end{tabular}


iodide portion in 3 was installed by anE-selective Takai olefination (>97:3, ${ }^{1} \mathrm{H}$ NMR analysis) with a combined yield of $78 \%$ over three steps.

The synthetic sequence depicted in Scheme 3 is shorter than our previously reported preparation ${ }^{16}$ of 3 when the step count

Scheme 3. Organocatalytic Approach to the Construction of $\omega$-3 Fragment 3
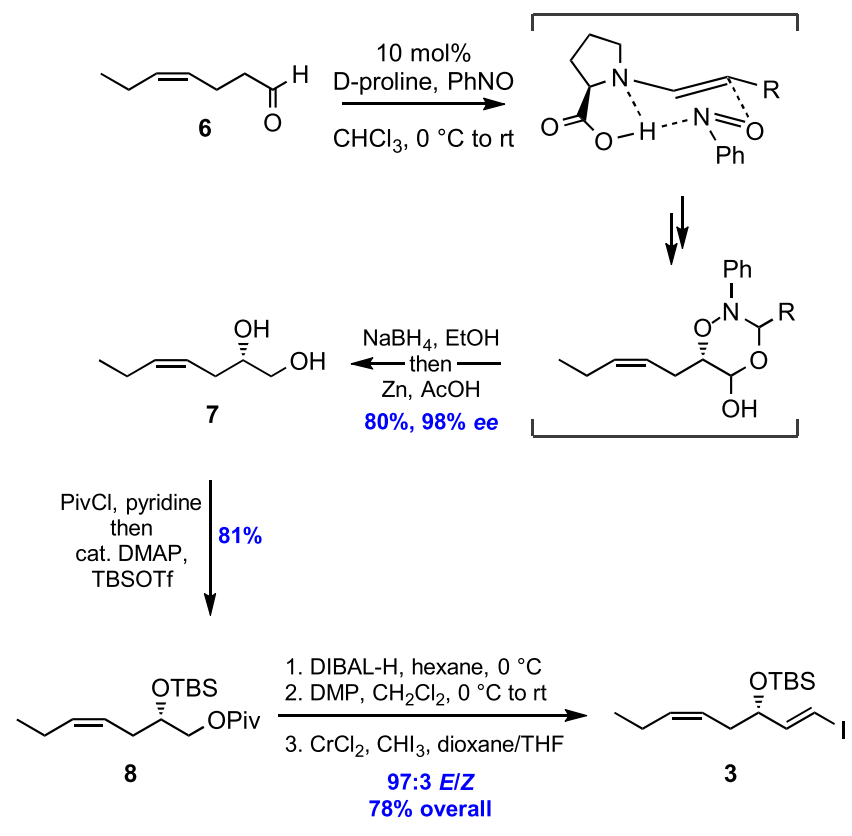

for one-pot reactions is taken into account. Furthermore, this approach comes with other benefits: for example, (i) the catalytic, highly enantioselective oxyamination replaces the rather expensive use of chiral pool starting materials of unreliable supply, (ii) the thoughtful use of reaction telescoping $^{17}$ allows for the conduction of several transformations without the need to isolate, purify, and handle sensitive intermediates, and (iii) cryogenic conditions combined with an array of hazardous reagents and additives have been avoided.

Turning our attention to the preparation of $\alpha$-fragment 5, the first step was the straight-forward esterification of lactone 9 in basic methanol and a subsequent copper-catalyzed Stahl aerobic oxidation ${ }^{18}$ of the resulting primary alcohol 10, affording 11 in good yield. The Carreira alkynylation ${ }^{19}$ between aldehyde 11 and 2-methylbut-3-yn-2-ol was studied next, and we found that a yield of $50 \%$ could be achieved if a solution of the aldehyde in toluene was added dropwise with the aid of a syringe pump, over a $24 \mathrm{~h}$ period, to two equivalents of the corresponding alkynylzinc species of said alkyne (Scheme 4). Slow addition is often needed for $\alpha$ unbranched aliphatic aldehydes in order to minimize the competing aldol self-condensation pathway. ${ }^{20}$

Surprisingly, however, chiral HPLC analysis of the 2naphthoate derivative of $\mathbf{1 2}$ revealed that the obtained enantiomeric excess was only $34 \%$ in this case (Supporting Information), which is significantly lower than what we have previously obtained for other structurally similar substrates in hitherto unpublished work. Hence, in light of this outcome, the alkynylation sequence was put to the side in favor of an alternative approach (Scheme 5).

Capitalizing on the $\beta$-silicon effect, an aliphatic FriedelCrafts acylation between acid chloride 13 and bis-
Scheme 4. Initial Approach toward 5 Utilizing the Carreira Alkynylation
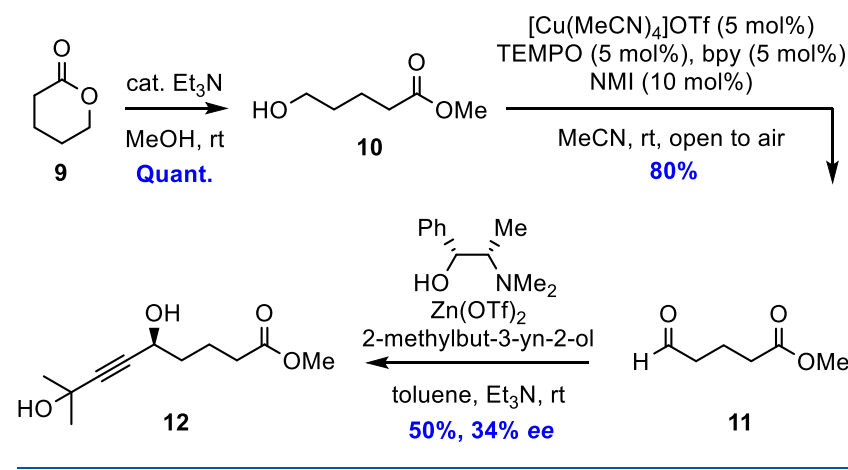

Scheme 5. Application of the Midland (S)-Alpine Borane Reduction in the Preparation of Fragment 16
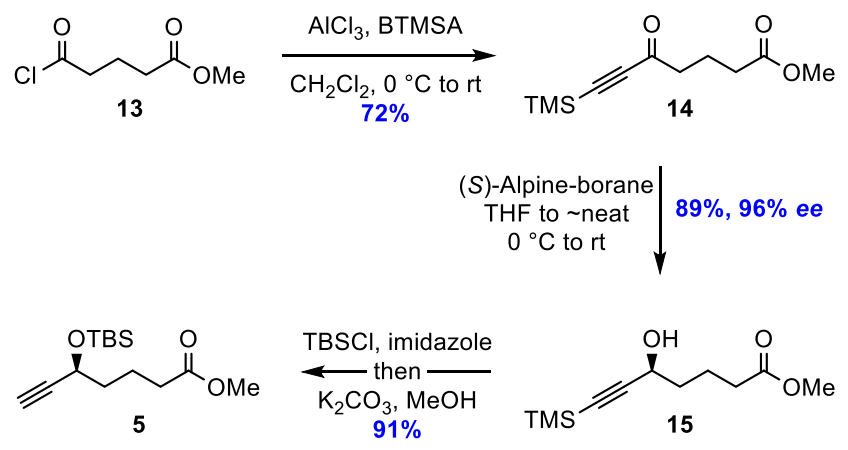

\begin{tabular}{r|r}
$74 \%$ over & $\begin{array}{r}\text { 1. } \mathrm{nBu}_{3} \mathrm{SnH}, \mathrm{AIBN} \\
\text { benzene, } 80{ }^{\circ} \mathrm{C}\end{array}$ \\
two steps & $\begin{array}{l}\text { 2. } \mathrm{I}_{2}, \mathrm{CH}_{2} \mathrm{Cl}_{2} \\
\end{array}$
\end{tabular}

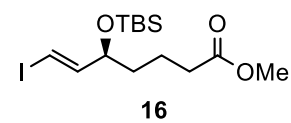

(trimethylsilyl)acetylene in the presence of Lewis acidic $\mathrm{AlCl}_{3}$, gave ketone 14 in $72 \%$ yield. ${ }^{21}$ Gram-scale asymmetric reduction of the alkynyl ketone was achieved by the addition of the Midland $(S)$-Alpine borane reagent ${ }^{22}$ in tetrahydrofuran (THF) at $0{ }^{\circ} \mathrm{C}$, followed by swift removal of the solvent to give essentially neat conditions, ultimately furnishing the desired propargylic alcohol 15 in $96 \%$ enantiomeric excess and 89\% yield after workup and purification (Supporting Information). The secondary alcohol in $\mathbf{1 5}$ was then protected using TBS chloride and imidazole in dichloromethane, followed by a solvent switch to methanol and addition of $\mathrm{K}_{2} \mathrm{CO}_{3}$, effectively removing the TMS-group attached to alkyne 5 in $91 \%$ overall yield.

At this stage, it was necessary to convert the terminal acetylene into the corresponding E-vinyl iodide, and this was achieved by a two-step process: first, free radical hydrostannation was initiated using a catalytic amount of azobisisobutyronitrile (AIBN), with excess tributyltin hydride added to ensure complete equilibration to the desired geometrical isomer, and then, iododestannylation was performed, yielding 16 in 74\% over two steps.

The first of the two planned Sonogashira cross-coupling reactions was performed using catalytic amounts of $\mathrm{Pd}$ - 
$\left(\mathrm{PPh}_{3}\right)_{2} \mathrm{Cl}_{2} / \mathrm{CuI}$, which cleanly effected the union between vinyl iodide 16 and linchpin 4 in $98 \%$ yield. Given the inherent lability of the resulting diyne system in 17 , especially to basic reaction conditions, protiodesilylation was performed in a mild manner by the employment of $\mathrm{AgNO}_{3}$ and $\mathrm{KCN},{ }^{23}$ affording the terminal alkyne 18 in $65 \%$ yield.

The same catalyst system was then used again for the final Sonogashira carbon-carbon bond-forming reaction between alkyne 18 and vinyl iodide 3, giving the complete carbon skeleton 19 in $78 \%$. The two internal, conjugated triple bonds were reduced in $70 \%$ yield using the tried-and-tested Lindlar hydrogenation protocol which involves the utilization of a mixed solvent system consisting of EtOAc/pyridine/1octene. $^{24}$ The inclusion of pyridine helps to modulate and control the activity of the heterogeneous catalyst, and 1-octene serves as a sacrificial olefin, the presence of which aids in minimizing competing over-reduction as the reaction nears completion. Removal of the two TBS-groups in 20 was first attempted using tetra- $n$-butylammonium fluoride (TBAF) in THF; however, significant byproduct formation was observed, leading to a diminished yield and difficulties during the purification process. A different deprotection approach was thus sought and found. Subjecting 20 instead to a catalytic amount of acetic chloride in methanol ${ }^{25}$ afforded RvE4 methyl ester (2) in 66\% yield (Scheme 6) and chemical purity $>97 \%$ (Supporting Information). The NMR- $\left({ }^{1} \mathrm{H},{ }^{13} \mathrm{C}\right.$, and COSY), MS-, and UV-data were all in accordance with the structure of 2 (Supporting Information).

MRM LC-MS/MS Matching Experiments. Since SPMs are formed in the nano- to picogram range in vivo, direct NMR analyses for structural verification are not viable. In order to ascertain that our synthetically prepared material was identical to that of authentic $\mathrm{RvE} 4$ (1) produced in vitro, matching experiments were conducted. Due to the chemically sensitive nature of this and other SPMs, ${ }^{26}$ hydrolysis was performed just prior to the LC-MS/MS experiments, as earlier reported. ${ }^{8}$ In Figure 2, top panel, the targeted MRM chromatogram from biogenic RvE4 (1) is shown together with an MS/MS spectrum displaying the molecular ion at $m / z 333(\mathrm{M}-\mathrm{H})$ as well as the accompanying daughter ions $(\mathrm{m} / z 315(\mathrm{M}-\mathrm{H}$ $\left.-\mathrm{H}_{2} \mathrm{O}\right), m / z 271\left(\mathrm{M}-\mathrm{H}-\mathrm{H}_{2} \mathrm{O}-\mathrm{CO}_{2}\right), m / z 253(\mathrm{M}-\mathrm{H}$ $\left.-2 \mathrm{H}_{2} \mathrm{O}-\mathrm{CO}_{2}\right), m / z 235, m / z 217\left(235-\mathrm{H}_{2} \mathrm{O}\right), m / z 199$ $\left(217-\mathrm{H}_{2} \mathrm{O}\right), m / z 191\left(235-\mathrm{CO}_{2}\right)$, and $m / z 173(235-$ $\mathrm{H}_{2} \mathrm{O}-\mathrm{CO}_{2}$ ) and $m / z$ 115). In the middle panel, the chromatographic behavior of synthetically produced RvE4 (1), with an identical observed retention time $(12.9 \mathrm{~min})$ to that of the authentic material, is shown. Next, the result from coinjection of the biologically produced material and synthetically produced RvE4 (1) appears in the bottom panel, resulting in both coelution as well as an overall matching MS/MS fragmentation fingerprint. Additionally, the UV-Vis spectrum was in agreement with the original isolation of $\operatorname{RvE} 4(1){ }^{8}$ Overall, these results confirm that the synthetic material matched the biogenic material.

\section{CONCLUSIONS}

A total synthesis providing multi-milligram quantities of the methyl ester 2 of the SPM RvE4 (1) has been reported in $10 \%$ yield over 10 steps (longest linear sequence). Several of the reactions were performed using telescoping techniques, establishing the basis for an efficient total synthesis. Moreover, the successful use of the organocatalytic MacMillian oxyamination reaction is presented. The application of stereo-
Scheme 6. Sonogashira Cross-Coupling Reactions and ZSelective Hydrogenation to Complete the Synthesis of RvE4 Methyl Ester (2)

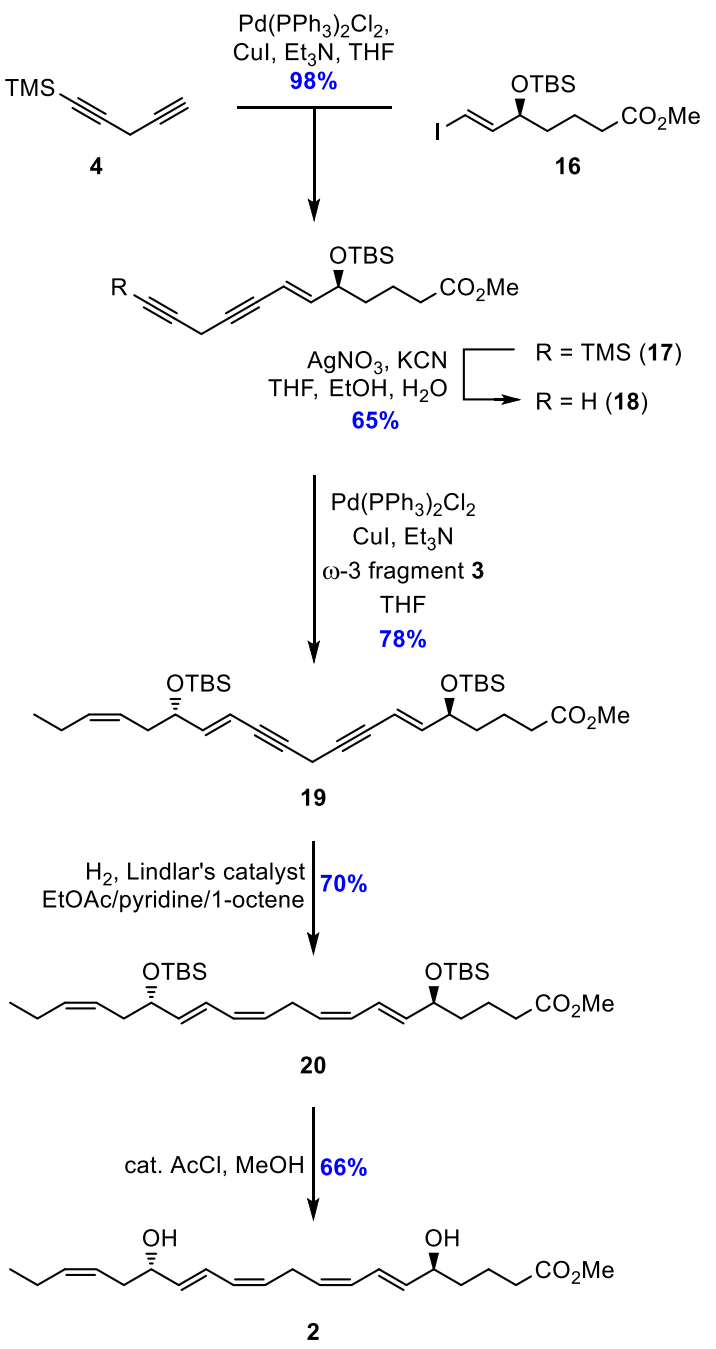

selective organocatalytic protocols offers many advantages in the total synthesis of natural products. ${ }^{27}$ The integrity of the synthetically prepared material was demonstrated through matching experiments with authentic material obtained from human macrophages and neutrophils during hypoxic conditions. These results showed that synthetic and biologically produced RvE4 (1) matched, thus establishing both the absolute configurations of the carbinol atoms as well as an overall alkene geometry. Collectively, this provided evidence for the complete stereochemical assignment as $(5 S, 6 E, 8 Z, 11$ $Z, 13 E, 15 S, 17 Z)$-5,15-dihydroxyicosa-6,8,11,13,17-pentaenoic acid.

\section{EXPERIMENTAL SECTION}

General Information. Unless otherwise stated, all commercially available reagents and solvents were used in the form they were supplied without any further purification. The stated yields are based on the isolated material. All sensitive reactions were performed under an argon or nitrogen atmosphere using Schlenk techniques. Reaction flasks were covered with aluminum foil during sensitive reactions and storage to minimize exposure to light. Thin layer chromatography was performed on silica gel $60 \mathrm{~F}_{254}$ aluminum-backed plates fabricated by Merck. Flash column chromatography was performed on silica gel 60 $(40-63 \mu \mathrm{m})$ produced by Merck. NMR spectra were recorded on a 

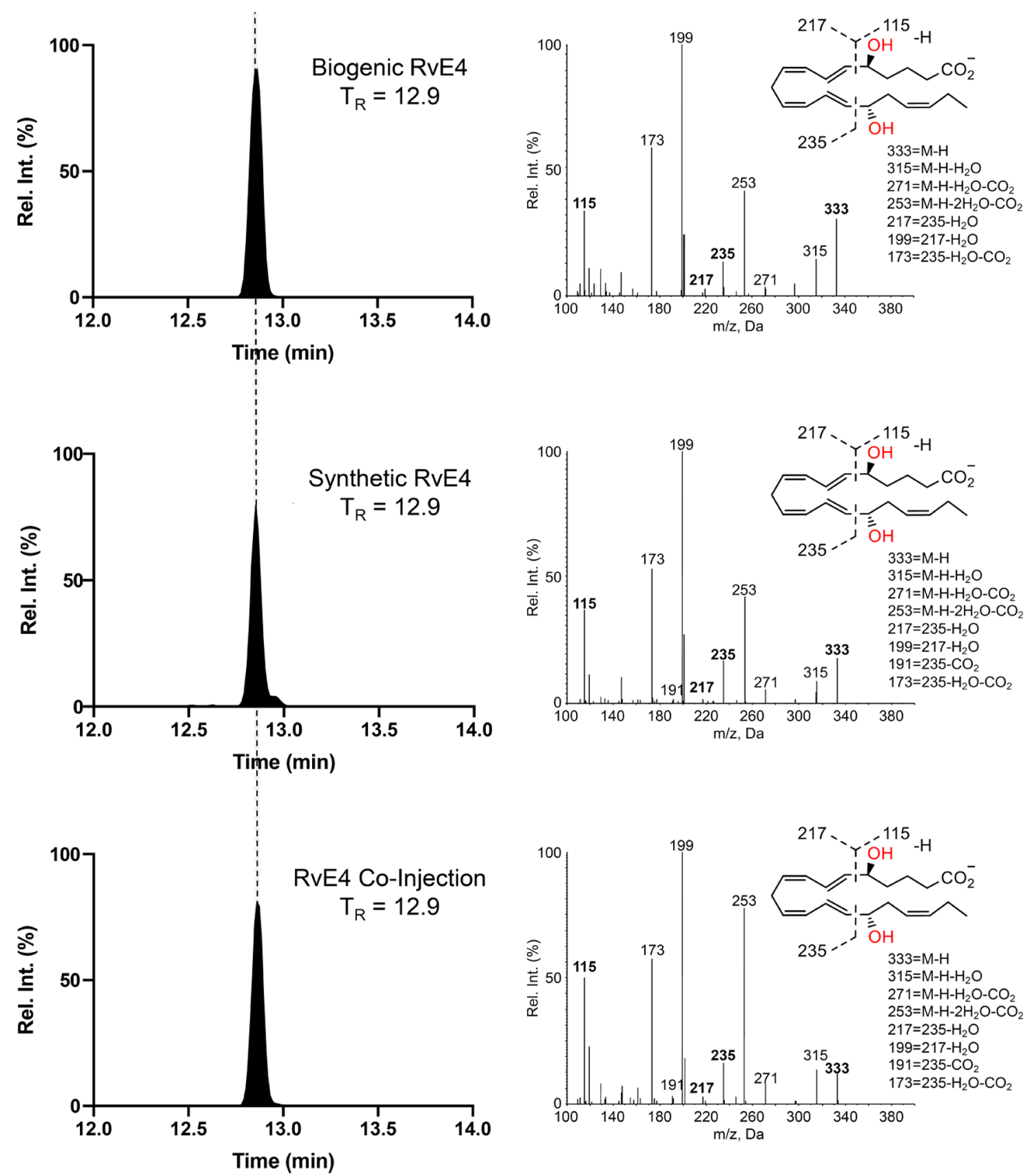

Figure 2. MRM chromatograms and MS/MS spectra obtained from the matching experiments.

Bruker AVII400 or Bruker DPX300 spectrometer at 400 or $300 \mathrm{MHz}$, respectively for ${ }^{1} \mathrm{H}$ NMR and at 101 or $75 \mathrm{MHz}$, respectively for ${ }^{13} \mathrm{C}$ NMR. Coupling constants $(J)$ are reported in hertz, and chemical shifts are reported in parts per million $(\delta)$ relative to the central residual protium solvent resonance in ${ }^{1} \mathrm{H} \mathrm{NMR}\left(\mathrm{CDCl}_{3}=\delta 7.26\right.$, DMSO- $d_{6}=\delta 2.50$ and MeOD $\left.=\delta 3.31\right)$ and the central carbon solvent resonance in ${ }^{13} \mathrm{C} \mathrm{NMR}\left(\mathrm{CDCl}_{3}=\delta 77.00 \mathrm{ppm}\right.$, DMSO- $d_{6}=\delta$ 39.43 and $\mathrm{MeOD}=\delta 49.00)$. Optical rotations were measured using a PerkinElmer 341 polarimeter. Mass spectra were recorded at $70 \mathrm{eV}$ on a Micromass Prospec Q or Micromass QTOF 2 W spectrometer using ESI as the method of ionization. High-resolution mass spectra were recorded at $70 \mathrm{eV}$ on a Micromass Prospec Q or Micromass QTOF $2 \mathrm{~W}$ spectrometer using ESI as the method of ionization. HPLCanalyses were performed using an $\mathrm{AD}-\mathrm{H}$ stationary phase (CHIRALPAK, $4.6 \times 250 \mathrm{~mm}$, particle size $5 \mu \mathrm{m}$, from Diacel Corporation) or a $\mathrm{C}_{18}$ stationary phase (Eclipse $\mathrm{XDBC}_{18}, 4.6 \times 250 \mathrm{~mm}$, particle size $5 \mu \mathrm{m}$, from Agilent Technologies), applying the conditions stated.
The UV-Vis spectrum was recorded using an Agilent Technologies Cary 8485 UV-Vis spectrophotometer using quartz cuvettes.

$(+)-(S, Z)$-Hept-4-ene-1,2-Diol (7). Diol 7 was prepared according to the literature with minor adjustments. ${ }^{13 \mathrm{~d}, \mathrm{e}}$ Nitrosobenzene (536 mg, $5.00 \mathrm{mmol}, 1.00$ equiv) and D-proline $(58.0 \mathrm{mg}, 0.500$ mmol, $10.0 \mathrm{~mol} \%)$ were dissolved in $\mathrm{CHCl}_{3}(2.5 \mathrm{~mL})$ and cooled to $0{ }^{\circ} \mathrm{C}$. cis-4-Heptenal $(6,1.98 \mathrm{~mL}, 1.68 \mathrm{~g}, 15.0 \mathrm{mmol}, 3.00$ equiv) was added dropwise, and the reaction was stirred at $0{ }^{\circ} \mathrm{C}$ for $2 \mathrm{~h}$. The reaction mixture was then added dropwise to a solution of $\mathrm{NaBH}_{4}$ (567 mg, $15.0 \mathrm{mmol}, 3.00$ equiv) in $\mathrm{EtOH}(30 \mathrm{~mL})$ at $0{ }^{\circ} \mathrm{C}$ and stirred at this temperature for an additional $2 \mathrm{~h}$. The solvent was removed in vacuo and to the product was added sat. aq. $\mathrm{NaHCO}_{3}(10$ $\mathrm{mL})$ followed by extraction with EtOAc $(3 \times 10 \mathrm{~mL})$. The combined organic phase was dried $\left(\mathrm{Na}_{2} \mathrm{SO}_{4}\right)$ and concentrated in vacuo. The product was dissolved in $\mathrm{EtOH} / \mathrm{AcOH}(3: 1,28.0 \mathrm{~mL})$, and zinc powder $(3.27 \mathrm{~g}, 50.0 \mathrm{mmol}, 10.0$ equiv) was added. The reaction mixture was stirred at room temperature overnight, filtrated through Celite, and concentrated in vacuo. The material thus obtained was 
purified by flash column chromatography $\left(\mathrm{SiO}_{2}\right.$, gradient elution, 50$70 \%$ EtOAc in hexane) to give the desired diol $7(522 \mathrm{mg}, 4.01 \mathrm{mmol}$, $80 \%)$ as a clear oil. $R_{\mathrm{f}}\left(50 \%\right.$ EtOAc in hexane, visualized by $\mathrm{KMnO}_{4}-$ stain $)=0.32 ;[\alpha]_{\mathrm{D}}^{25}=+9.5\left(c 1.0, \mathrm{CHCl}_{3}\right)\left[\mathrm{Lit.}^{28}[\alpha]_{\mathrm{D}}^{25}=+9.0(c 1.0\right.$, $\left.\left.\mathrm{CHCl}_{3}\right)\right] ;{ }^{1} \mathrm{H}$ NMR (400 MHz, MeOD): $\delta 5.55-5.35(\mathrm{~m}, 2 \mathrm{H})$, $3.67-3.55(\mathrm{~m}, 1 \mathrm{H}), 3.50(\mathrm{dd}, J=11.1,4.3 \mathrm{~Hz}, 1 \mathrm{H}), 3.42(\mathrm{dd}, J=$ $11.1,6.5 \mathrm{~Hz}, 1 \mathrm{H}), 2.35-2.23(\mathrm{~m}, 1 \mathrm{H}), 2.22-2.12(\mathrm{~m}, 1 \mathrm{H}), 2.08(\mathrm{p}, J$ $=7.4 \mathrm{~Hz}, 2 \mathrm{H}), 0.97(\mathrm{t}, J=7.5 \mathrm{~Hz}, 3 \mathrm{H}) ;{ }^{13} \mathrm{C}\left\{{ }^{1} \mathrm{H}\right\}$ NMR $(101 \mathrm{MHz}$, MeOD): $\delta$ 134.6, 125.8, 73.4, 66.8, 32.3, 21.6, 14.6; HRESIMS $m / z$ : $153.0885[\mathrm{M}+\mathrm{Na}]^{+}$(calcd for $\left.\mathrm{C}_{7} \mathrm{H}_{14} \mathrm{O}_{2} \mathrm{Na}, 153.0886\right)$.

A small amount of the $\alpha$-aminoxylated alcohol intermediate was kept for HPLC analysis. The enantiomeric excess (98\%) was determined by HPLC analysis using a chiral column (AD- $\mathrm{H}, i$ $\mathrm{PrOH} /$ hexane, 5:95, $1.0 \mathrm{~mL} / \mathrm{min}): t_{\mathrm{r}}($ major $)=19.54 \mathrm{~min}, t_{\mathrm{r}}($ minor $)$ $=26.13 \mathrm{~min}$.

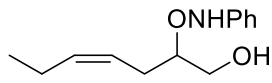

21

(Z)-2-((Phenylamino)oxy)hept-4-en-1-ol (21). Nitrosobenzene (96.0 $\mathrm{mg}, 0.884 \mathrm{mmol}, 1.00$ equiv) and DL-proline (10.4 mg, 88.4 $\mu \mathrm{mol}, 10.0 \mathrm{~mol} \%)$ were dissolved in $\mathrm{CHCl}_{3}(0.45 \mathrm{~mL})$ and cooled to $0{ }^{\circ} \mathrm{C}$. cis-4-Heptenal $(6,0.354 \mathrm{~mL}, 300 \mathrm{mg}, 2.65 \mathrm{mmol}, 3.00$ equiv) was added dropwise, and the reaction was stirred at $0{ }^{\circ} \mathrm{C}$ for $2 \mathrm{~h}$. The reaction mixture was added dropwise to a solution of $\mathrm{NaBH}_{4}(102$ $\mathrm{mg}, 2.65 \mathrm{mmol}, 3.00$ equiv) in $\mathrm{EtOH}(5.4 \mathrm{~mL})$ at $0{ }^{\circ} \mathrm{C}$ and stirred at the same temperature for an additional $2 \mathrm{~h}$. The solvent was removed in vacuo, and to the crude product was added sat. aq. $\mathrm{NaHCO}_{3}(1.8$ $\mathrm{mL})$ followed by extraction with EtOAc $(3 \times 2 \mathrm{~mL})$ and the combined organic phase was dried $\left(\mathrm{Na}_{2} \mathrm{SO}_{4}\right)$, filtrated and concentrated in vacuo. The crude product thus obtained was filtrated through a short plug of silica gel (50\% EtOAc in hexane) to yield the desired $\alpha$-aminoxylated alcohol intermediate 21 (176 mg, 0.796 mmol, $90 \%)$ as a yellow oil. $R_{\mathrm{f}}(20 \%$ EtOAc in hexane, visualized by $\mathrm{UV}$ and $\mathrm{KMnO}_{4}$ stain $)=0.28 ;{ }^{1} \mathrm{H} \mathrm{NMR}\left(400 \mathrm{MHz}, \mathrm{CDCl}_{3}\right): \delta 7.38-$ $7.26(\mathrm{~m}, 3 \mathrm{H}), 7.05-7.01(\mathrm{~m}, 2 \mathrm{H}), 5.63-5.51(\mathrm{~m}, 1 \mathrm{H}), 5.48-5.38$ (m, $1 \mathrm{H}), 4.10-3.96(\mathrm{~m}, 1 \mathrm{H}), 3.88(\mathrm{dd}, J=12.1,2.8 \mathrm{~Hz}, 1 \mathrm{H}), 3.79$ (dd, $J=12.1,6.5 \mathrm{~Hz}, 1 \mathrm{H}), 2.50($ app dt, $J=13.7,6.6 \mathrm{~Hz}, 1 \mathrm{H}), 2.37$ (app dt, $J=14.7,7.5 \mathrm{~Hz}, 1 \mathrm{H}), 2.10(\mathrm{p}, J=7.3 \mathrm{~Hz}, 1 \mathrm{H}), 1.00(\mathrm{t}, J=$ $7.5 \mathrm{~Hz}, 3 \mathrm{H}) ;{ }^{13} \mathrm{C}\left\{{ }^{1} \mathrm{H}\right\}$ NMR (101 MHz, $\left.\mathrm{CDCl}_{3}\right): \delta 148.5,134.7$, 129.2 (2C), 123.8, 122.7, 115.0 (2C), 84.0, 64.9, 28.1, 20.8, 14.3; HRESIMS $m / z: 244.1306[\mathrm{M}+\mathrm{Na}]^{+}$(calcd for $\mathrm{C}_{13} \mathrm{H}_{19} \mathrm{NO}_{2} \mathrm{Na}$, 244.1308)

(S,Z)-2-((tert-Butyldimethylsilyl)oxy)hept-4-en-1-yl Pivalate (8). Diol 7 (200 mg, $1.54 \mathrm{mmol}, 1.00$ equiv) was dissolved in a 1:1 mixture of $\mathrm{CH}_{2} \mathrm{Cl}_{2} /$ pyridine $(4.6 \mathrm{~mL})$ and cooled to $0{ }^{\circ} \mathrm{C}$. Then, trimethylacetyl chloride $(0.227 \mathrm{~mL}, 1.85 \mathrm{mmol}, 1.20$ equiv $)$ was added dropwise. The reaction mixture was stirred at $0{ }^{\circ} \mathrm{C}$ until deemed complete by TLC (30\% EtOAc in hexane, $\sim 2 \mathrm{~h}$ ). TBSOTf $(0.88 \mathrm{~mL}, 3.83 \mathrm{mmol}, 2.50$ equiv) was then added dropwise followed by addition of one crystal of DMAP. Stirring was continued at $0{ }^{\circ} \mathrm{C}$ until deemed complete by TLC ( $30 \%$ EtOAc in hexane, $\sim 2 \mathrm{~h}$ ). The reaction mixture was quenched with sat. aq. $\mathrm{NaHCO}_{3}(10 \mathrm{~mL})$, extracted with EtOAc $(3 \times 5 \mathrm{~mL})$, dried $\left(\mathrm{Na}_{2} \mathrm{SO}_{4}\right)$, filtrated, and concentrated in vacuo. The crude product thus obtained was purified by flash chromatography $\left(\mathrm{SiO}_{2}, 2 \%\right.$ EtOAc in hexane) to yield $\mathbf{8}$ (409 $\mathrm{mg}, 1.25 \mathrm{mmol}, 81 \%)$ as a clear oil. $R_{\mathrm{f}}(3.5 \% \mathrm{EtOAc}$ in hexane, visualized by $\mathrm{KMnO}_{4}$-stain $)=0.29 ;[\alpha]_{\mathrm{D}}^{25}=+7.0\left(c 0.1, \mathrm{CH}_{2} \mathrm{Cl}_{2}\right) ;{ }^{1} \mathrm{H}$ NMR (400 MHz, CDCl $): \delta 5.53-5.43(\mathrm{~m}, 1 \mathrm{H}), 5.40-5.33(\mathrm{~m}, 1 \mathrm{H})$, $3.99(\mathrm{dd}, J=11.0,5.2 \mathrm{~Hz}, 1 \mathrm{H}), 3.93(\mathrm{dd}, J=11.0,5.3 \mathrm{~Hz}, 1 \mathrm{H}), 3.87$ $(\mathrm{p}, J=5.6 \mathrm{~Hz}, 1 \mathrm{H}), 2.36-2.17(\mathrm{~m}, 2 \mathrm{H}), 2.04(\mathrm{p}, J=7.5 \mathrm{~Hz}, 2 \mathrm{H})$, $1.21(\mathrm{~s}, 9 \mathrm{H}), 0.96(\mathrm{t}, J=7.5 \mathrm{~Hz}, 3 \mathrm{H}), 0.88(\mathrm{~s}, 9 \mathrm{H}), 0.08-0.07(2 \times \mathrm{s}$, $6 \mathrm{H}) ;{ }^{13} \mathrm{C}\left\{{ }^{1} \mathrm{H}\right\} \mathrm{NMR}\left(101 \mathrm{MHz}, \mathrm{CDCl}_{3}\right): \delta 178.6,134.2,124.1,70.3$, 67.8, 38.9, 32.6, 27.4 (3C), 25.9 (3C), 20.8, 18.2, 14.3, -4.5, -4.5; HRESIMS $m / z: 351.2325[\mathrm{M}+\mathrm{Na}]^{+}$(calcd for $\mathrm{C}_{18} \mathrm{H}_{36} \mathrm{O}_{3} \mathrm{SiNa}$, 351.2326).

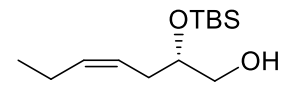

22

(S,Z)-2-((tert-Butyldimethylsilyl)oxy)hept-4-en-1-ol (22). The pivalate 8 (674 mg, $2.05 \mathrm{mmol}, 1.00$ equiv) was dissolved in hexane $(4.8 \mathrm{~mL})$ and cooled to $0{ }^{\circ} \mathrm{C}$. DIBAL-H $(1.0 \mathrm{M}$ in hexane, $5.13 \mathrm{~mL}$, $5.13 \mathrm{mmol}, 2.50$ equiv) was added dropwise, and the reaction mixture was stirred until deemed complete by TLC (20\% EtOAc in hexane, $\sim 2 \mathrm{~h}) . \mathrm{MeOH}(2.7 \mathrm{~mL})$ was added to quench the reaction followed by addition of sat. aq. potassium sodium tartrate $(27 \mathrm{~mL})$. The aqueous phase was extracted with $\mathrm{Et}_{2} \mathrm{O}(3 \times 7 \mathrm{~mL})$. The combined organic phase was dried $\left(\mathrm{Na}_{2} \mathrm{SO}_{4}\right)$, filtrated, concentrated in vacuo, and then kept under high vacuum for $2 \mathrm{~h}$. The resulting alcohol intermediate was used without further purification in the next step. $R_{\mathrm{f}}$ $\left(20 \%\right.$ EtOAc in hexane, visualized by $\mathrm{KMnO}_{4}$-stain $)=0.48 ;[\alpha]_{\mathrm{D}}^{25}=$ +19.8 (c 0.1, $\mathrm{CH}_{2} \mathrm{Cl}_{2}$ ); ${ }^{1} \mathrm{H}$ NMR $\left(400 \mathrm{MHz}, \mathrm{CDCl}_{3}\right): \delta 5.53-5.40$ $(\mathrm{m}, 1 \mathrm{H}), 5.39-5.25(\mathrm{~m}, 1 \mathrm{H}), 3.79-3.71(\mathrm{~m}, 1 \mathrm{H}), 3.56(\mathrm{dd}, J=11.0$, $3.6 \mathrm{~Hz}, 1 \mathrm{H}), 3.44$ (dd, $J=11.0,5.5 \mathrm{~Hz}, 1 \mathrm{H}), 2.35-2.17(\mathrm{~m}, 2 \mathrm{H}), 2.05$ (p, $J=7.4 \mathrm{~Hz}, 2 \mathrm{H}), 1.86-1.73($ br s, $1 \mathrm{H}), 0.96(\mathrm{t}, J=7.5 \mathrm{~Hz}, 3 \mathrm{H})$, $0.91(\mathrm{~s}, 9 \mathrm{H}), 0.10(\mathrm{~s}, 3 \mathrm{H}), 0.09(\mathrm{~s}, 3 \mathrm{H}) ;{ }^{13} \mathrm{C}\left\{{ }^{1} \mathrm{H}\right\}$ NMR $(101 \mathrm{MHz}$, $\left.\mathrm{CDCl}_{3}\right): \delta 134.3,124.2,72.9,66.1,32.1,26.0$ (3C), 20.8, 18.2, 14.3, $-4.3,-4.5$; HRESIMS $m / z$ : 267.1751 $[\mathrm{M}+\mathrm{Na}]^{+}$(calcd for $\left.\mathrm{C}_{13} \mathrm{H}_{28} \mathrm{O}_{2} \mathrm{SiNa}, 267.1751\right)$.

tert-Butyl(((S,1E,5Z)-1-iodoocta-1,5-dien-3-yl)oxy)dimethylsilane (3). Alcohol 22 was dissolved in $\mathrm{CH}_{2} \mathrm{Cl}_{2}(60 \mathrm{~mL})$ and cooled to $0{ }^{\circ} \mathrm{C}$. The Dess-Martin periodinane reagent $(1.04 \mathrm{~g}, 2.45 \mathrm{mmol}$, 1.20 equiv) was then added in one portion. The reaction mixture was removed from the cooling bath, and stirring was continued for $4 \mathrm{~h}$. The reaction was quenched by addition of sat. aq. $\mathrm{Na}_{2} \mathrm{~S}_{2} \mathrm{O}_{3}(13 \mathrm{~mL})$, and the phases were separated. The aqueous phase was extracted with $\mathrm{CH}_{2} \mathrm{Cl}_{2}(2 \times 15 \mathrm{~mL})$. The combined organic phase was dried $\left(\mathrm{Na}_{2} \mathrm{SO}_{4}\right)$, filtrated, and concentrated in vacuo. The crude product thus obtained was filtrated through a short plug of silica gel $(10 \%$ EtOAc in hexane, $R_{\mathrm{f}}(10 \%$ EtOAc in hexane $\left.)=0.52\right)$ to remove the leftover and spent DMP-reagent and then concentrated in vacuo.

A $50 \mathrm{~mL}$ flask was charged with $\mathrm{CrCl}_{2}(2.02 \mathrm{~g}, 16.4 \mathrm{mmol}, 8.00$ equiv), and the salt was dried under high-vacuum using a heat gun, cooled to ambient temperature, and covered with aluminum foil. Dry THF $(2.8 \mathrm{~mL})$ and dry dioxane $(16 \mathrm{~mL})$ were added, and the resulting suspension was cooled to $0{ }^{\circ} \mathrm{C}$ before $\mathrm{CHI}_{3}(2.03 \mathrm{~g}, 5.13$ mmol, 2.50 equiv) was added. The reaction mixture was stirred at room temperature for $2 \mathrm{~h}$, at which point the mixture turned from dark-green to red-brown. The reaction mixture was cooled to $0{ }^{\circ} \mathrm{C}$, and the aldehyde dissolved in dry dioxane $(2.0 \mathrm{~mL})$ was added in a dropwise manner, and the reaction mixture was stirred for $2 \mathrm{~h}$ at room temperature. The reaction was quenched by the addition of sat. aq. $\mathrm{NH}_{4} \mathrm{Cl}(10 \mathrm{~mL})$. The aqueous phase was extracted with $\mathrm{Et}_{2} \mathrm{O}(3 \times 7$ $\mathrm{mL})$. The combined organic phase was washed successively with sat. aq. $\mathrm{Na}_{2} \mathrm{~S}_{2} \mathrm{O}_{3}(\sim 2 \mathrm{~mL})$ and brine, dried $\left(\mathrm{Na}_{2} \mathrm{SO}_{4}\right)$, filtrated, and concentrated in vacuo. The crude product thus obtained was purified by flash chromatography $\left(\mathrm{SiO}_{2}\right.$, gradient elution, $0-1 \%$ EtOAc in hexane) to yield vinyl iodide $3(586 \mathrm{mg}, 1.60 \mathrm{mmol}, 78 \%$ from $8, E / Z$ $=97: 3)$ as a pale yellow oil. $R_{\mathrm{f}}(1 \%$ EtOAc in hexane, visualized by $\mathrm{UV}$ and $\mathrm{KMnO}_{4}$ stain $)=0.50 ;[\alpha]_{\mathrm{D}}^{20}=-4.1$ (c 0.3, benzene); ${ }^{1} \mathrm{H}$ NMR $\left(400 \mathrm{MHz}, \mathrm{CDCl}_{3}\right): \delta 6.54(\mathrm{dd}, J=14.3,5.7 \mathrm{~Hz}, 1 \mathrm{H}), 6.21$ $(\mathrm{dd}, J=14.4,1.3 \mathrm{~Hz}, 1 \mathrm{H}), 5.53-5.43(\mathrm{~m}, 1 \mathrm{H}), 5.38-5.24(\mathrm{~m}, 1 \mathrm{H})$, 4.16-3.99 (m, 1H), 2.29-2.17 (m, 2H), 2.08-1.97 (m, 2H), $0.96(\mathrm{t}$, $J=7.5 \mathrm{~Hz}, 3 \mathrm{H}), 0.89(\mathrm{~s}, 9 \mathrm{H}), 0.05(\mathrm{~s}, 3 \mathrm{H}), 0.04(\mathrm{~s}, 3 \mathrm{H}) ;{ }^{13} \mathrm{C}\left\{{ }^{1} \mathrm{H}\right\}$ $\operatorname{NMR}\left(101 \mathrm{MHz}, \mathrm{CDCl}_{3}\right): \delta 148.9,134.4,123.8,75.9,75.2,35.7,26.0$ (3C), 20.9, 18.4, 14.4, -4.5, -4.7; HRESIMS $m / z: 389.0768[\mathrm{M}+$ $\mathrm{Na}]^{+}$(calcd for $\mathrm{C}_{14} \mathrm{H}_{27} \mathrm{IOSiNa}, 389.0768$ ).

Methyl 5-Hydroxypentanoate (10). To a solution of $\delta$ valerolactone $(9,5.0 \mathrm{~g}, 50 \mathrm{mmol}, 1.0$ equiv) in $\mathrm{MeOH}(50 \mathrm{~mL})$ was added triethylamine $(2.4 \mathrm{~mL}, 17 \mathrm{mmol}, 34 \mathrm{~mol} \%)$. The reaction was stirred for $18 \mathrm{~h}$ at room temperature. The reaction mixture was then filtrated through a short plug of silica gel, and the plug was washed with additional $\mathrm{MeOH}$ and concentrated in vacuo to yield the desired methyl ester 10 (6.6 g, $50 \mathrm{mmol}$, quant.) as a clear oil. The product was used as is in the next reaction. The spectroscopic data 
was in agreement with previously reported data. ${ }^{29}{ }^{1} \mathrm{H}$ NMR (400 MHz, DMSO- $\left.d_{6}\right): \delta 4.38(\mathrm{t}, J=5.2 \mathrm{~Hz}, 1 \mathrm{H}), 3.58(\mathrm{~s}, 3 \mathrm{H}), 3.38$ (app $\mathrm{td}, J=6.4,5.2 \mathrm{~Hz}, 2 \mathrm{H}), 2.30(\mathrm{t}, J=7.4 \mathrm{~Hz}, 2 \mathrm{H}), 1.70-1.47(\mathrm{~m}, 2 \mathrm{H})$, 1.46-1.32 (m, 2H); ${ }^{13} \mathrm{C}\left\{{ }^{1} \mathrm{H}\right\}$ NMR (101 MHz, DMSO): $\delta$ 173.4, 60.2, 51.2, 33.1, 31.8, 21.2.

Methyl 5-Oxopentanoate (11). Alcohol 10 (200 mg, 1.51 mmol, 1.00 equiv) was dissolved in $\mathrm{MeCN}(15 \mathrm{~mL})$. [Cu( $\left.\mathrm{MeCN})_{4}\right]$ OTf $(28.3 \mathrm{mg}, 75.1 \mu \mathrm{mol}, 5.00 \mathrm{~mol} \%)$ and commercial Stahl aerobic oxidation TEMPO solution $(0.47 \mathrm{~mL})$ were added, and the reaction was stirred open to air until complete as deemed by TLC. The reaction mixture was diluted with $\mathrm{Et}_{2} \mathrm{O}(15 \mathrm{~mL})$ and filtrated through a short plug of silica gel. The plug was washed with additional $\mathrm{Et}_{2} \mathrm{O}$. The solvent was removed in vacuo, and the crude product thus obtained was purified by flash column chromatography $\left(\mathrm{SiO}_{2}, 16 \%\right.$ EtOAc in hexane) to yield the desired aldehyde 11 (158 mg, 1.21 $\mathrm{mmol}, 80 \%)$ as a clear oil. The spectroscopic data was in agreement with previously reported data. ${ }^{30} R_{\mathrm{f}}(14 \%$ EtOAc in hexane, visualized by $\mathrm{KMnO}_{4}$-stain $)=0.15 ;{ }^{1} \mathrm{H} \mathrm{NMR}\left(400 \mathrm{MHz}, \mathrm{CDCl}_{3}\right): \delta 9.77(\mathrm{t}, J=$ $1.3 \mathrm{~Hz}, 1 \mathrm{H}), 3.67(\mathrm{~s}, 3 \mathrm{H}), 2.53(\mathrm{td}, J=7.2,1.3 \mathrm{~Hz}, 2 \mathrm{H}), 2.37(\mathrm{t}, J=$ $7.2 \mathrm{~Hz}, 2 \mathrm{H}), 1.95(\mathrm{p}, J=7.2 \mathrm{~Hz}, 2 \mathrm{H}) ;{ }^{13} \mathrm{C}\left\{{ }^{1} \mathrm{H}\right\} \mathrm{NMR}(101 \mathrm{MHz}$, $\left.\mathrm{CDCl}_{3}\right): \delta 201.6,173.5,51.8,43.0,33.1,17.5$.

Methyl (S)-5-((tert-Butyldimethylsilyl)oxy)-8-hydroxy-8methylnon-6-ynoate (12). $\mathrm{Zn}(\mathrm{OTf})_{2}(559 \mathrm{mg}, 1.54 \mathrm{mmol}, 2.00$ equiv) was added to a flame-dried flask under argon and dried under high vacuum at $120{ }^{\circ} \mathrm{C}$ overnight. The flask was cooled and vented with argon, before $(1 R, 2 S)-(-)-N$-methylephedrine $(289 \mathrm{mg}, 1.61$ mmol, 2.10 equiv) was added. The flask was purged with argon $(\sim 15$ $\min )$, and then, toluene $(1.3 \mathrm{~mL})$ and triethylamine $(225 \mu \mathrm{L}, 1.61$ mmol, 2.10 equiv) were added. The reaction mixture was stirred for 2 $\mathrm{h}$ followed by the addition of 2-methyl-3-butyn-2-ol (149 $\mu \mathrm{L}, 1.54$ $\mathrm{mmol}, 2.00$ equiv). The content of the flask was stirred for $20 \mathrm{~min}$ before starting the addition of aldehyde $11(100 \mathrm{mg}, 0.768 \mathrm{mmol}$, 1.00 equiv), dissolved in toluene $(1.8 \mathrm{~mL}$ ) using a syringe pump over $24 \mathrm{~h}$. The reaction was quenched by the addition of sat. aq. $\mathrm{NH}_{4} \mathrm{Cl}$ $(\sim 5 \mathrm{~mL})$ and extracted with ether $(5 \times 5 \mathrm{~mL})$. The organic phase was dried $\left(\mathrm{Na}_{2} \mathrm{SO}_{4}\right)$, filtrated, and concentrated in vacuo. The material thus obtained was purified by flash chromatography $\left(\mathrm{SiO}_{2}, 50 \%\right.$ EtOAc in hexane), yielding diol $\mathbf{1 2}(82.3 \mathrm{mg}, 0.384 \mathrm{mmol}, 50 \%)$ as a clear oil. $R_{\mathrm{f}}\left(50 \%\right.$ EtOAc in hexane, visualized by $\mathrm{KMnO}_{4}$-stain $)=$ 0.13; $[\alpha]_{\mathrm{D}}^{25}=-0.9(c 1.0, \mathrm{MeOH}) ;{ }^{1} \mathrm{H}$ NMR (400 MHz, MeOD): $\delta$ $4.33(\mathrm{t}, J=6.4 \mathrm{~Hz}, 1 \mathrm{H}), 3.66(\mathrm{~s}, 3 \mathrm{H}), 2.37(\mathrm{t}, J=7.3 \mathrm{~Hz}, 2 \mathrm{H}), 1.81-$ $1.72(\mathrm{~m}, 2 \mathrm{H}) 1.71-1.61(\mathrm{~m}, 2 \mathrm{H}), 1.46(\mathrm{~s}, 6 \mathrm{H}) ;{ }^{13} \mathrm{C}\left\{{ }^{1} \mathrm{H}\right\}$ NMR $(101$ $\mathrm{MHz}, \mathrm{MeOD}): \delta 175.7,90.3,83.6,65.4,62.4,52.0,49.4,38.2,34.4$, $31.7,21.9$; HRESIMS $m / z: 237.1098[\mathrm{M}+\mathrm{Na}]^{+}$(calcd for $\mathrm{C}_{11} \mathrm{H}_{18} \mathrm{O}_{4} \mathrm{Na}$, 237.1097).

Methyl 5,8-Dihydroxy-8-methylnon-6-ynoate (rac-12). 2Methyl-3-butyn-2-ol ( $74.5 \mu \mathrm{L}, 0.786 \mathrm{mmol}, 1.00$ equiv) in THF $(34 \mathrm{~mL})$ was cooled to $-78{ }^{\circ} \mathrm{C} . n \mathrm{BuLi}(1.6 \mathrm{M}$ in hexane, $0.983 \mathrm{~mL}$, $1.57 \mathrm{mmol}, 2.00$ equiv) was added dropwise over $15 \mathrm{~min}$. The reaction mixture was stirred for $30 \mathrm{~min}$ before aldehyde $\mathbf{1 1}(100 \mathrm{mg}$, $0.768 \mathrm{mmol}, 1.00$ equiv) in THF $(1.74 \mathrm{~mL})$ was added dropwise. After $2 \mathrm{~h}$ at $-78^{\circ} \mathrm{C}$, the reaction was quenched by addition of sat. aq. $\mathrm{NH}_{4} \mathrm{Cl}(7 \mathrm{~mL})$ and extracted with EtOAc $(3 \times 5 \mathrm{~mL})$. The combined organic phase was dried $\left(\mathrm{Na}_{2} \mathrm{SO}_{4}\right)$, filtrated, and concentrated in vacuo. The material thus obtained was purified by flash chromatography $\left(\mathrm{SiO}_{2}, 50 \%\right.$ EtOAc in hexane), yielding diol rac-12 $(62.0 \mathrm{mg}$, $0.289 \mathrm{mmol}, 37 \%)$ as a clear oil. The obtained experimental data matched that given for compound $\mathbf{1 2}$.

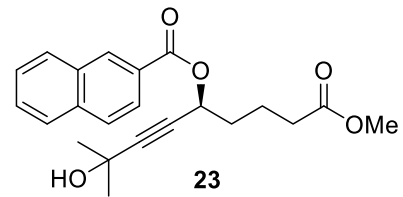

(S)-7-Methoxy-7-oxo-1-(trimethylsilyl)hept-1-yn-3-yl 2Naphthoate (23). Propargylic alcohol $12(20.0 \mathrm{mg}, 93.3 \mu \mathrm{mol}$, 1.00 equiv) was dissolved in $\mathrm{CH}_{2} \mathrm{Cl}_{2}(0.43 \mathrm{~mL})$ and cooled to $0{ }^{\circ} \mathrm{C}$. Triethylamine $(39.0 \mu \mathrm{L}, 0.280 \mathrm{mmol}, 3.00$ equiv) was added followed by DMAP (1.10 mg, $9.00 \mu \mathrm{mol}, 10.0 \mathrm{~mol} \%$ ). Next, 2-naphthoyl chloride ( $21.4 \mathrm{mg}, 0.112 \mathrm{mmol}, 1.20$ equiv) was added in one portion.
The reaction mixture was allowed to warm up to room temperature and stirred overnight. The solvent was removed under a gentle stream of argon, and the material thus obtained was purified by flash column chromatography $\left(\mathrm{SiO}_{2}\right.$, gradient elution, $10-30 \%$ EtOAc in hexane) to give the desired naphthalate 23 (31.5 mg, $85.6 \mu \mathrm{mol}, 92 \%$ ) as a white solid. The enantiomeric excess (34\%) was determined by HPLC analysis using a chiral column (AD-H, $i-\mathrm{PrOH} /$ hexane, 15:85, $1.0 \mathrm{~mL} / \mathrm{min}): t_{\mathrm{r}}($ major $)=17.44 \mathrm{~min}, t_{\mathrm{r}}($ minor $)=21.99 \min . R_{\mathrm{f}}(30 \%$ EtOAc in hexane, visualized by $\mathrm{UV}$ and $\mathrm{KMnO}_{4}$ stain $)=0.18 ;[\alpha]_{\mathrm{D}}^{25}=$ $+10.5\left(\right.$ c 0.6, $\left.\mathrm{CHCl}_{3}\right) ;{ }^{1} \mathrm{H}$ NMR $(300 \mathrm{MHz}, \mathrm{MeOD}): \delta 8.61(\mathrm{~s}, 1 \mathrm{H})$, $8.13-7.80(\mathrm{~m}, 4 \mathrm{H}), 7.61(\mathrm{p}, J=7.1 \mathrm{~Hz}, 2 \mathrm{H}), 5.72(\mathrm{t}, J=5.8 \mathrm{~Hz}, 1 \mathrm{H})$, $3.66(\mathrm{~s}, 3 \mathrm{H}), 2.46(\mathrm{t}, J=6.6 \mathrm{~Hz}, 2 \mathrm{H}), 1.93(\mathrm{~m}, 4 \mathrm{H}), 1.47(\mathrm{~s}, 6 \mathrm{H})$; ${ }^{13} \mathrm{C}\left\{{ }^{1} \mathrm{H}\right\}$ NMR (101 MHz, MeOD): $\delta 175.4,166.9,137.1,133.9$, 132.2, 130.4, 129.7, 129.4, 128.9, 128.3, 128.0, 126.0, 92.2, 79.7, 65.6, 65.4, 52.1, 35.3, 34.1, 31.6, 21.7 (2C); HRESIMS $m / z: 391.1516[\mathrm{M}$ $+\mathrm{Na}]^{+}$(calcd for $\left.\mathrm{C}_{22} \mathrm{H}_{24} \mathrm{O}_{5} \mathrm{Na}, 391.1516\right)$.

The exact same procedure was followed for the preparation of racemic naphthalate. Yield: $30.8 \mathrm{mg}, 0.0837 \mathrm{mmol}, 90 \%$. The obtained experimental data matched that given for compound 23 .

Methyl 5-0xo-7-(trimethylsilyl)hept-6-ynoate (14). A flamedried flask under argon was charged with $\mathrm{AlCl}_{3}(10.5 \mathrm{~g}, 78.8 \mathrm{mmol}$, 1.30 equiv) and $\mathrm{CH}_{2} \mathrm{Cl}_{2}(75 \mathrm{~mL})$ at $0{ }^{\circ} \mathrm{C}$. A solution of bis(trimethylsilyl)acetylene (10.4 g, $60.8 \mathrm{mmol}, 1.00$ equiv) and methyl 4-(chloroformyl)butyrate (13, $10.0 \mathrm{~g}, 60.8 \mathrm{mmol}, 1.00$ equiv) in $\mathrm{CH}_{2} \mathrm{Cl}_{2}(75 \mathrm{~mL})$ was then added in a dropwise manner over 15 min. The reaction mixture was stirred at $0{ }^{\circ} \mathrm{C}$ for $30 \mathrm{~min}$, warmed up to room temperature over a period of $45 \mathrm{~min}$, and then cooled back down to $0{ }^{\circ} \mathrm{C}$. The reaction was quenched by the addition of $1 \mathrm{M}$ $\mathrm{HCl}(80 \mathrm{~mL})$ and stirred for $10 \mathrm{~min}$. The resulting thick suspension was vacuum filtrated through a short plug of silica gel directly into a separatory funnel, and the plug was washed with additional fresh $\mathrm{CH}_{2} \mathrm{Cl}_{2}(50 \mathrm{~mL})$. The phases were separated, and the aqueous phase was extracted with $\mathrm{CH}_{2} \mathrm{Cl}_{2}(3 \times 50 \mathrm{~mL})$. The combined organic phase was dried $\left(\mathrm{Na}_{2} \mathrm{SO}_{4}\right)$, filtrated, and concentrated in vacuo. The crude product thus obtained was purified by flash column chromatography $\left(\mathrm{SiO}_{2}, 10 \%\right.$ EtOAc in hexane) to yield the desired product $14(9.90 \mathrm{~g}, 43.7 \mathrm{mmol} 72 \%)$ as a yellow oil. The spectroscopic data was in agreement with previously reported data. ${ }^{31} R_{\mathrm{f}}\left(10 \%\right.$ EtOAc in hexane, visualized by $\mathrm{KMnO}_{4}$-stain $)=$ $0.27 ;{ }^{1} \mathrm{H}$ NMR $\left(400 \mathrm{MHz}, \mathrm{CDCl}_{3}\right): \delta 3.68(\mathrm{~s}, 3 \mathrm{H}), 2.65(\mathrm{t}, J=7.2$ $\mathrm{Hz}, 2 \mathrm{H}), 2.37(\mathrm{t}, J=7.3 \mathrm{~Hz}, 2 \mathrm{H}), 1.97(\mathrm{p}, J=7.3 \mathrm{~Hz}, 2 \mathrm{H}), 0.24(\mathrm{~s}$, $9 \mathrm{H}) ;{ }^{13} \mathrm{C}\left\{{ }^{1} \mathrm{H}\right\}$ NMR $\left(101 \mathrm{MHz}, \mathrm{CDCl}_{3}\right): \delta 186.8,173.5,101.9,98.3$, $51.8,44.3,32.9,19.1,-0.6$ (3C); HRESIMS $m / z: 249.0917[\mathrm{M}+$ $\mathrm{Na}]^{+}$(calcd for $\mathrm{C}_{11} \mathrm{H}_{18} \mathrm{O}_{3} \mathrm{SiNa}$, 249.0917).

Methyl (S)-5-Hydroxy-7-(trimethylsilyl)hept-6-ynoate (15). Ketone 14 (5.66 g, $25.0 \mathrm{mmol}, 1.00$ equiv) was azeotropically dried with 2 -MeTHF $(2 \times 15 \mathrm{~mL})$ and then placed under high vacuum for $30 \mathrm{~min}$. The flask was vented with argon and cooled to $-10{ }^{\circ} \mathrm{C}$, and (S)-Alpine-borane solution (0.5 M in THF, $100 \mathrm{~mL}, 50.0 \mathrm{mmol}, 2.00$ equiv) was added over a period of $15 \mathrm{~min}$. Most of the THF solvent was immediately removed under vacuum with efficient stirring while warming up to $0{ }^{\circ} \mathrm{C}$. The resulting, highly viscous reaction mixture was then allowed to warm to room temperature and stirred overnight. Next, the reaction mixture was cooled to $0{ }^{\circ} \mathrm{C}$, and acetaldehyde $(1.40$ $\mathrm{mL}, 1.10 \mathrm{~g}, 25.0 \mathrm{mmol}, 1.00$ equiv) was added in a dropwise manner. After $15 \mathrm{~min}$, diethyl ether $(100 \mathrm{~mL})$ was added, followed by the dropwise addition of ethanolamine $(3.00 \mathrm{~mL}, 3.00 \mathrm{~g}, 50.0 \mathrm{mmol}, 2.00$ equiv). The reaction mixture was stirred for $30 \mathrm{~min}$ at $0{ }^{\circ} \mathrm{C}$, warmed to room temperature, and then stirred an additional hour. The white, solid 9-BBN-ethanolamine complex was removed by filtration, and the filtrate was washed with water $(2 \times 30 \mathrm{~mL})$. The organic phase was dried $\left(\mathrm{Na}_{2} \mathrm{SO}_{4}\right)$, filtrated, and concentrated in vacuo. The crude product thus obtained was purified by flash column chromatography ( $\mathrm{SiO}_{2}$, gradient elution, $10-20 \%$ EtOAc in hexane) to give the desired product $15(5.10 \mathrm{~g}, 22.3 \mathrm{mmol}, 89 \%)$ as a clear oil. $R_{\mathrm{f}}(20 \%$ EtOAc in hexane, visualized by $\mathrm{KMnO}_{4}$-stain $)=0.21 ;[\alpha]_{\mathrm{D}}^{20}=-1.0($ c 1.0, $\left.\mathrm{CHCl}_{3}\right)\left[\right.$ Lit. $\left.^{32}[\alpha]_{\mathrm{D}}^{21}=-0.7\left(c 1.1, \mathrm{CHCl}_{3}\right)\right]$; ${ }^{1} \mathrm{H}$ NMR $(400 \mathrm{MHz}$, $\left.\mathrm{CDCl}_{3}\right): \delta 4.37(\mathrm{t}, J=6.2 \mathrm{~Hz}, 1 \mathrm{H}), 3.67(\mathrm{~s}, 3 \mathrm{H}), 2.38(\mathrm{t}, J=7.1 \mathrm{~Hz}$, $2 \mathrm{H}), 1.91(\mathrm{~s}, 1 \mathrm{H}), 1.85-1.68(\mathrm{~m}, 4 \mathrm{H}), 0.16(\mathrm{~s}, 9 \mathrm{H}) ;{ }^{13} \mathrm{C}\left\{{ }^{1} \mathrm{H}\right\} \mathrm{NMR}$ $\left(101 \mathrm{MHz}, \mathrm{CDCl}_{3}\right): \delta 174.0,106.5,89.8,62.5,51.7,37.0,33.7,20.7$, 
0.0 (3C); HRESIMS $m / z: 251.1073[\mathrm{M}+\mathrm{Na}]^{+}$(calcd for $\mathrm{C}_{11} \mathrm{H}_{20} \mathrm{O}_{3} \mathrm{SiNa}$, 251.1074).

Methyl 5-Hydroxy-7-(trimethylsilyl)hept-6-ynoate (rac-15). Ketone 14 (200 mg, $0.884 \mathrm{mmol}, 1.00$ equiv) was azeotropically dried with 2-MeTHF $(2 \times 1 \mathrm{~mL})$ and then placed under high vacuum for $30 \mathrm{~min}$. The flask was cooled to $0{ }^{\circ} \mathrm{C}$, and $9-\mathrm{BBN}-\mathrm{H}(0.5 \mathrm{M}$ in THF, $3.53 \mathrm{~mL}, 1.77 \mathrm{mmol}, 2.00$ equiv) was added, and approximately half the solvent volume was removed under vacuum at room temperature. The reaction mixture was stirred for $72 \mathrm{~h}$ before acetaldehyde $(0.05$ $\mathrm{mL}, 0.884 \mathrm{mmol}, 1.00$ equiv) was added dropwise, and the reaction mixture was stirred for an additional hour. The reaction mixture was diluted with $\mathrm{Et}_{2} \mathrm{O}(5 \mathrm{~mL})$, and ethanolamine $(53.0 \mu \mathrm{L}, 0.884 \mathrm{mmol}$, 1.00 equiv) was added in a dropwise manner. After $30 \mathrm{~min}$, the reaction mixture was concentrated in vacuo to give a yellow oil together with some solid material. Water $(5 \mathrm{~mL})$ was added, and the aqueous phase was extracted with $\mathrm{Et}_{2} \mathrm{O}(3 \times 3 \mathrm{~mL})$. The organic phase was dried $\left(\mathrm{Na}_{2} \mathrm{SO}_{4}\right)$, filtrated, and concentrated in vacuo. The crude material thus obtained was purified by flash column chromatography $\left(\mathrm{SiO}_{2}\right.$, gradient elution, $10-20 \%$ EtOAc in hexane) to give the desired racemic product rac-15 $(109 \mathrm{mg}, 0.477 \mathrm{mmol}$, $54 \%)$ as a clear oil. The obtained experimental data matched that given for compound 15 .

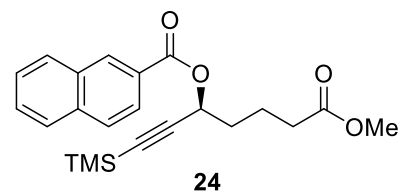

(S)-7-Methoxy-7-oxo-1-(trimethylsilyl)hept-1-yn-3-yl 2Naphthoate (24). Propargylic alcohol $15(25.0 \mathrm{mg}, 0.109 \mathrm{mmol}$, 1.00 equiv) was dissolved in $\mathrm{CH}_{2} \mathrm{Cl}_{2}(0.5 \mathrm{~mL})$ and cooled to $0{ }^{\circ} \mathrm{C}$. Triethylamine ( $46.0 \mu \mathrm{L}, 0.327 \mathrm{mmol}, 3.00$ equiv) was added followed by DMAP (1.30 mg, $10.9 \mu \mathrm{mol}, 10.0 \mathrm{~mol} \%)$. Next, 2-naphthoyl chloride $(25 \mathrm{mg}, 0.131 \mathrm{mmol}, 1.20$ equiv) was added in one portion. The reaction mixture was allowed to warm up to room temperature and stirred overnight. The solvent was removed under a gentle stream of argon, and then, hexane $(2 \mathrm{~mL})$ and sat. aq. $\mathrm{NaH}_{2} \mathrm{PO}_{4}(2 \mathrm{~mL})$ were added. After $5 \mathrm{~min}$ of vigorous stirring, the organic phase was separated and the aqueous phase was extracted with hexane $(2 \times 2$ $\mathrm{mL})$. The combined organic phase was dried $\left(\mathrm{Na}_{2} \mathrm{SO}_{4}\right)$, filtrated, and concentrated in vacuo. The material thus obtained was purified by flash column chromatography $\left(\mathrm{SiO}_{2}\right.$, gradient elution, 0-10\% EtOAc in hexane) to give the desired naphthalate $24(39.0 \mathrm{mg}, 0.102 \mathrm{mmol}$, $93 \%$ ) as a white solid. The enantiomeric excess (96\%) was determined by HPLC analysis using a chiral column (AD-H, $i-$ $\mathrm{PrOH} /$ hexane, $2: 98,1.0 \mathrm{~mL} / \mathrm{min}): t_{\mathrm{r}}($ major $)=13.63 \mathrm{~min}, t_{\mathrm{r}}($ minor $)$ $=12.54 \mathrm{~min} . R_{\mathrm{f}}\left(10 \%\right.$ EtOAc in hexane, visualized by $\mathrm{UV}$ and $\mathrm{KMnO}_{4}$ stain $)=0.22 ;[\alpha]_{\mathrm{D}}^{25}=+6.2\left(c 0.2, \mathrm{CHCl}_{3}\right) ;{ }^{1} \mathrm{H} \mathrm{NMR}(400 \mathrm{MHz}$, $\left.\mathrm{CDCl}_{3}\right): \delta 8.64(\mathrm{~s}, 1 \mathrm{H}), 8.08(\mathrm{dd}, J=8.6,1.7 \mathrm{~Hz}, 1 \mathrm{H}), 7.98(\mathrm{~d}, J=8.0$ $\mathrm{Hz}, 1 \mathrm{H}), 7.89(\mathrm{dd}, J=8.4,2.1 \mathrm{~Hz}, 2 \mathrm{H}), 7.64-7.52(\mathrm{~m}, 2 \mathrm{H}), 5.72(\mathrm{t}, J$ $=6.2 \mathrm{~Hz}, 1 \mathrm{H}), 3.68(\mathrm{~s}, 3 \mathrm{H}), 2.44(\mathrm{t}, J=7.3 \mathrm{~Hz}, 2 \mathrm{H}), 2.07-1.96(\mathrm{~m}$, $2 \mathrm{H}), 1.95-1.87(\mathrm{~m}, 2 \mathrm{H}), 0.18(\mathrm{~s}, 9 \mathrm{H}) ;{ }^{13} \mathrm{C}\left\{{ }^{1} \mathrm{H}\right\}$ NMR (101 MHz, $\left.\mathrm{CDCl}_{3}\right): \delta 173.7,165.7,135.8,132.6,131.5,129.6,128.5,128.3$, 127.9, 127.3, 126.8, 125.5, 102.3, 91.2, 64.6, 51.8, 34.5, 33.6, 20.7, 0.0 (3C); HRESIMS $m / z: 405.1492[\mathrm{M}+\mathrm{Na}]^{+}$(calcd for $\mathrm{C}_{22} \mathrm{H}_{26} \mathrm{O}_{4} \mathrm{SiNa}, 405.1493$ ).

The exact same procedure was followed for the preparation of racemic naphthalate. Yield: $30.0 \mathrm{mg}, 78.5 \mu \mathrm{mol}, 72 \%$. The obtained experimental data matched that given for compound 24 .

Methyl (S)-5-((tert-Butyldimethylsilyl)oxy)hept-6-ynoate (5). Propargylic alcohol 15 (3.90 g, $17.1 \mathrm{mmol}, 1.00$ equiv) was dissolved in $\mathrm{CH}_{2} \mathrm{Cl}_{2}(45 \mathrm{~mL})$. Imidazole $(2.33 \mathrm{~g}, 34.2 \mathrm{mmol}, 2.00$ equiv) and tert-butyldimethylsilyl chloride (3.86 g, $25.6 \mathrm{mmol}, 1.50$ equiv) were added in a successive manner at room temperature. The reaction mixture was stirred overnight and then the solvent was removed in vacuo. The material was dissolved in methanol $(172 \mathrm{~mL})$ and then cooled to $0{ }^{\circ} \mathrm{C}$. Next, $\mathrm{K}_{2} \mathrm{CO}_{3}(4.74 \mathrm{~g}, 34.2 \mathrm{mmol}, 2.00$ equiv) was added in one portion, and the reaction mixture was allowed to warm to room temperature. The reaction was followed by TLC analysis (product is observed just below the starting material with 5\% EtOAc in hexane as the eluent), and when deemed complete by TLC analysis $(\sim 1 \mathrm{~h})$, the flask was cooled back down to $0{ }^{\circ} \mathrm{C}$. The reaction was quenched by the addition of phosphate buffer $(132 \mathrm{~mL}$, $\mathrm{pH}=7)$, and the reaction mixture was stirred for $5 \mathrm{~min} . \mathrm{NaCl}(\sim 10$ g) was added, and the aqueous phase was extracted with hexane $(5 \times$ $50 \mathrm{~mL})$. The combined organic phase was dried $\left(\mathrm{Na}_{2} \mathrm{SO}_{4}\right)$, filtrated, and concentrated in vacuo. The crude material thus obtained was purified by flash column chromatography $\left(\mathrm{SiO}_{2}, 5 \% \mathrm{EtOAc}\right.$ in hexane) to give the desired product $5(4.21 \mathrm{~g}, 15.6 \mathrm{mmol}, 91 \%)$ as a clear oil. The spectroscopic data was in agreement with previously reported data. ${ }^{33} R_{\mathrm{f}}$ (5\% EtOAc in hexane, visualized by $\mathrm{KMnO}_{4}$-stain) $=0.24 ;[\alpha]_{\mathrm{D}}^{20}=-36.2(c 0.2, \mathrm{MeOH})\left[\mathrm{Lit}^{34}[\alpha]_{\mathrm{D}}^{20}=-36(c \quad 0.2\right.$, $\mathrm{MeOH})] ;{ }^{1} \mathrm{H}$ NMR $\left(400 \mathrm{MHz}, \mathrm{CDCl}_{3}\right): \delta 4.35(\mathrm{td}, J=6.0,2.1 \mathrm{~Hz}$, $1 \mathrm{H}), 3.65(\mathrm{~s}, 3 \mathrm{H}), 2.37(\mathrm{~d}, J=2.1 \mathrm{~Hz}, 1 \mathrm{H}), 2.34(\mathrm{t}, J=7.2 \mathrm{~Hz}, 2 \mathrm{H})$, $1.85-1.65(\mathrm{~m}, 4 \mathrm{H}), 0.88(\mathrm{~s}, 9 \mathrm{H}), 0.12(\mathrm{~s}, 3 \mathrm{H}), 0.09(\mathrm{~s}, 3 \mathrm{H}) ;{ }^{13} \mathrm{C}\left\{{ }^{1} \mathrm{H}\right\}$ NMR $\left(101 \mathrm{MHz} \mathrm{CDCl}_{3}\right): \delta 173.9,85.3,72.5,62.4,51.6,37.9,33.8$, $25.9,20.7,18.3,-5.0,-4.5$; HRESIMS $m / z: 293.1543[\mathrm{M}+\mathrm{Na}]^{+}$ (calcd for $\mathrm{C}_{14} \mathrm{H}_{26} \mathrm{O}_{3} \mathrm{SiNa}, 293.1543$ ).

Methyl (S,E)-5-((tert-Butyldimethylsilyl)oxy)-7-iodohept-6enoate (16). Vinyl iodide 16 was prepared following the procedure by Sulikowski et al. ${ }^{35}$ Alkyne 5 ( $100 \mathrm{mg}, 0.370 \mathrm{mmol}, 1.00$ equiv) was dissolved in benzene $(7.5 \mathrm{~mL})$, and then, $n \mathrm{Bu}_{3} \mathrm{SnH}(0.30 \mathrm{~mL}, 1.11$ mmol, 3.00 equiv) and AIBN (10.0 mg, $60.9 \mu \mathrm{mol}, 16.5 \mathrm{~mol} \%)$ were added. The reaction was heated to $80{ }^{\circ} \mathrm{C}$ (oil bath) for $2 \mathrm{~h}$. The reaction mixture was then cooled to room temperature, and the solvent was removed in vacuo. The crude product thus obtained was purified by flash column chromatography $\left(\mathrm{SiO}_{2}, 1 \% \mathrm{Et}_{2} \mathrm{O}\right.$ in hexane) to give the desired product as a clear oil which was used directly in the next reaction. $R_{\mathrm{f}}\left(5 \% \mathrm{Et}_{2} \mathrm{O}\right.$ in hexane, visualized with $\mathrm{KMnO}_{4}$ stain $)=$ 0.35 .

To a solution of the stannane intermediate $(170 \mathrm{mg}, 0.303 \mathrm{mmol}$, 1.00 equiv) in dry $\mathrm{CH}_{2} \mathrm{Cl}_{2}(1.2 \mathrm{~mL})$ was added dropwise a solution of $\mathrm{I}_{2}$ (115 mg, $0.454 \mathrm{mmol}, 1.50$ equiv) in dry $\mathrm{CH}_{2} \mathrm{Cl}_{2}(1.7 \mathrm{~mL})$ until the resulting solution maintained a slight pink color. The reaction was stirred for an additional $20 \mathrm{~min}$, followed by the addition of sat. aq. $\mathrm{Na}_{2} \mathrm{~S}_{2} \mathrm{O}_{3}(3 \mathrm{~mL}), \mathrm{H}_{2} \mathrm{O}(2 \mathrm{~mL})$, and sat. aq. $\mathrm{NaHCO}_{3}(3 \mathrm{~mL})$. The mixture was stirred for an additional $5 \mathrm{~min}$, the phases were separated, and the aqueous phase was extracted with $\mathrm{CH}_{2} \mathrm{Cl}_{2}(3 \times 10 \mathrm{~mL})$. The combined organic phase was dried $\left(\mathrm{MgSO}_{4}\right)$, filtrated, and concentrated in vacuo. The crude product thus obtained was purified by flash column chromatography $\left(\mathrm{SiO}_{2}, 5 \% \mathrm{Et}_{2} \mathrm{O}\right.$ in hexane) to obtain the vinyl iodide 16 (109 $\mathrm{mg}, 0.274 \mathrm{mmol}, 74 \%$ over two steps) as a clear oil. The spectroscopic data was in agreement with previously reported data. ${ }^{35} R_{\mathrm{f}}\left(5 \% \mathrm{Et}_{2} \mathrm{O}\right.$ in hexane, visualized by $\mathrm{UV}$ and $\mathrm{KMnO}_{4}$ stain $)=0.23 ;[\alpha]_{\mathrm{D}}^{20}=-25.8\left(c 1.7, \mathrm{CHCl}_{3}\right)\left[\mathrm{Lit}^{35}[\alpha]_{\mathrm{D}}^{20}=-25.8(c\right.$ $\left.\left.1.7, \mathrm{CHCl}_{3}\right)\right]$; ${ }^{1} \mathrm{H}$ NMR $\left(400 \mathrm{MHz}, \mathrm{CDCl}_{3}\right): \delta 6.50(\mathrm{dd}, J=14.4,6.0$ $\mathrm{Hz}, 1 \mathrm{H}), 6.22(\mathrm{dd}, J=14.4,1.3 \mathrm{~Hz}, 1 \mathrm{H}), 4.10$ (app qd, $J=5.9,1.3$ $\mathrm{Hz}, 1 \mathrm{H}), 3.67(\mathrm{~s}, 3 \mathrm{H}), 2.31(\mathrm{t}, J=7.3 \mathrm{~Hz}, 2 \mathrm{H}), 1.86-1.56(\mathrm{~m}, 2 \mathrm{H})$, $1.56-1.46(\mathrm{~m}, 2 \mathrm{H}), 0.89(\mathrm{~s}, 9 \mathrm{H}), 0.04(\mathrm{~s}, 3 \mathrm{H}), 0.03(\mathrm{~s}, 3 \mathrm{H}) ;{ }^{13} \mathrm{C}\left\{{ }^{1} \mathrm{H}\right\}$ NMR $\left(101 \mathrm{MHz}, \mathrm{CDCl}_{3}\right): \delta 174.0,148.9,76.2,74.9,52.2,36.9,34.0$, 25.9 (3C), 20.4, 18.3, -4.4, -4.8; HRESIMS $m / z: 421.0666[\mathrm{M}+$ $\mathrm{Na}]^{+}$(calcd for $\mathrm{C}_{14} \mathrm{H}_{27} \mathrm{IO}_{3} \mathrm{SiNa}$, 421.0666).

Methyl (S,E)-5-((tert-Butyldimethylsilyl)oxy)-12-(trimethylsilyl)dodeca-6-en-8,11-diynoate (17). Vinyl iodide 16 (818 mg, $2.05 \mathrm{mmol}, 1.00$ equiv) was dissolved in THF $(11 \mathrm{~mL})$. The solution was cooled to $0{ }^{\circ} \mathrm{C}$ before $\mathrm{Pd}\left(\mathrm{PPh}_{3}\right)_{2} \mathrm{Cl}_{2}(72.1 \mathrm{mg}, 0.103 \mathrm{mmol}, 5.0$ $\mathrm{mol} \%), \mathrm{CuI}$ (46.9 mg, $0.246 \mathrm{mmol}, 12.0 \mathrm{~mol} \%)$, and $\mathrm{Et}_{3} \mathrm{~N}(416 \mathrm{mg}$, $0.57 \mathrm{~mL}, 4.11 \mathrm{mmol}, 2.00$ equiv) were added. The alkyne $4(702 \mathrm{mg}$, $0.89 \mathrm{~mL}, 5.15 \mathrm{mmol}, 2.50$ equiv) was dissolved in THF $(0.63 \mathrm{~mL})$ and added dropwise. The reaction mixture was allowed to slowly warm to ambient temperature and stirred in the dark for an additional $16 \mathrm{~h}$. After completion, the reaction mixture was filtrated through a short plug of silica gel (15\% EtOAc in hexane) and concentrated in vacuo. The crude product thus obtained was purified by flash column chromatography $\left(\mathrm{SiO}_{2}, 5 \% \mathrm{EtOAc}\right.$ in hexane) to obtain the coupled product $17(820 \mathrm{mg}, 2.02 \mathrm{mmol}, 98 \%)$ as an orange/brown oil. $R_{\mathrm{f}}$ ( $5 \%$ EtOAc in hexane, visualized by UV and $\mathrm{KMnO}_{4}$ stain $)=0.25$; $[\alpha]_{\mathrm{D}}^{25}=-0.7$ (c 0.7, benzene); ${ }^{1} \mathrm{H}$ NMR $\left(400 \mathrm{MHz}, \mathrm{CDCl}_{3}\right): \delta 6.07$ $(\mathrm{dd}, J=15.9,5.6 \mathrm{~Hz}, 1 \mathrm{H}), 5.65-6.60(\mathrm{~m}, 1 \mathrm{H}), 4.19-4.15(\mathrm{~m}, 1 \mathrm{H})$, $3.66(\mathrm{~s}, 3 \mathrm{H}), 3.33(\operatorname{app~d}, J=2.2 \mathrm{~Hz}, 2 \mathrm{H}), 2.29(\mathrm{t}, J=7.4 \mathrm{~Hz}, 2 \mathrm{H})$, 
$1.69-1.61(\mathrm{~m}, 2 \mathrm{H}), 1.54-1.48(\mathrm{~m}, 2 \mathrm{H}), 0.89(\mathrm{~s}, 9 \mathrm{H}), 0.16(\mathrm{~s}, 9 \mathrm{H})$, $0.04(\mathrm{~s}, 3 \mathrm{H}), 0.03(\mathrm{~s}, 3 \mathrm{H}) ;{ }^{13} \mathrm{C}\left\{{ }^{1} \mathrm{H}\right\}$ NMR $\left(101 \mathrm{MHz}, \mathrm{CDCl}_{3}\right): \delta$ 174.0, 146.0, 109.1, 99.8, 85.4, 83.5, 79.1, 72.3, 51.6, 37.3, 34.1, 26.0 (3C), 20.5, 18.3, 11.7, 0.1 (3C), $-4.3,-4.7$; HRESIMS $\mathrm{m} / \mathrm{z}$ : $429.2251[\mathrm{M}+\mathrm{Na}]^{+}$(calcd for $\mathrm{C}_{22} \mathrm{H}_{38} \mathrm{O}_{3} \mathrm{Si}_{2} \mathrm{Na}, 429.2252$ ).

Methyl (S,E)-5-((tert-Butyldimethylsilyl)oxy)dodeca-6-en8,11-diynoate (18). The TMS-protected acetylene $17(66.0 \mathrm{mg}$ $0.162 \mathrm{mmol}, 1.00$ equiv) was dissolved in THF $(2.55 \mathrm{~mL})$ and EtOH (1.54 mL). A solution of $\mathrm{AgNO}_{3}(190 \mathrm{mg}, 0.642 \mathrm{mmol}, 3.90$ equiv) in a mixture of EtOH and $\mathrm{H}_{2} \mathrm{O}(1: 1,1.80 \mathrm{~mL})$ was added dropwise and stirred for $40 \mathrm{~min}$. The reaction mixture went from dark yellow to black after the addition of the $\mathrm{AgNO}_{3}$ solution. $\mathrm{KCN}(73.8 \mathrm{mg}, 1.13$ mmol, 7.00 equiv) was dissolved in $\mathrm{H}_{2} \mathrm{O}(1.3 \mathrm{~mL})$ and added dropwise at room temperature (precipitation was observed during this stage). The reaction was stirred for $2 \mathrm{~h}$ and quenched by the addition of $\mathrm{H}_{2} \mathrm{O}(20 \mathrm{~mL})$ and diluted by EtOAc $(30 \mathrm{~mL})$. The phases were separated, and the aqueous phase was extracted with EtOAc $(3 \times 30$ $\mathrm{mL})$. The combined organic phase was dried $\left(\mathrm{Na}_{2} \mathrm{SO}_{4}\right)$, filtrated, and concentrated in vacuo. The crude product thus obtained was purified by flash chromatography $\left(\mathrm{SiO}_{2}, 5 \%\right.$ EtOAc in hexane) to obtain product $18(35.3 \mathrm{mg}, 0.105 \mathrm{mmol}, 65 \%)$ as a yellow oil. $R_{\mathrm{f}}(10 \%$ EtOAc in hexane, visualized by $\mathrm{UV}$ and $\mathrm{KMnO}_{4}$ stain $)=0.21 ;[\alpha]_{\mathrm{D}}^{25}=$ -1.8 (c 0.6, benzene); ${ }^{1} \mathrm{H}$ NMR $\left(400 \mathrm{MHz}, \mathrm{CDCl}_{3}\right): \delta 6.08$ (dd, $J=$ $15.8,5.4 \mathrm{~Hz}, 1 \mathrm{H}), 5.63(\mathrm{dq}, J=15.9,2.0 \mathrm{~Hz}, 1 \mathrm{H}), 4.17(\mathrm{qd}, J=5.7$, $1.6 \mathrm{~Hz}, 1 \mathrm{H}), 3.66(\mathrm{~s}, 3 \mathrm{H}), 3.30(\mathrm{t}, J=2.4 \mathrm{~Hz}, 2 \mathrm{H}), 2.30(\mathrm{t}, J=7.4 \mathrm{~Hz}$, $2 \mathrm{H}), 2.08(\mathrm{t}, J=2.7 \mathrm{~Hz}, 1 \mathrm{H}), 1.69-1.60(\mathrm{~m}, 2 \mathrm{H}), 1.53-1.47(\mathrm{~m}$, $2 \mathrm{H}), 0.90(\mathrm{~s}, 9 \mathrm{H}),-0.04(\mathrm{~s}, 3 \mathrm{H}),-0.02(\mathrm{~s}, 3 \mathrm{H}) ;{ }^{3} \mathrm{C}\left\{{ }^{1} \mathrm{H}\right\} \operatorname{NMR}(101$ $\left.\mathrm{MHz}, \mathrm{CDCl}_{3}\right): \delta 174.1,146.3,108.8,83.1,79.3,78.2,72.2,69.0,51.6$, 37.2, 34.1, 26.0 (3C), 20.5, 18.3, 10.4, -4.4, -4.8; HRESIMS $m / z$ : $357.1855[\mathrm{M}+\mathrm{Na}]^{+}$(calcd for $\left.\mathrm{C}_{19} \mathrm{H}_{30} \mathrm{O}_{3} \mathrm{SiNa}, 357.1856\right)$.

Methyl (5S,6E,13E,15S,17Z)-5,15-Bis((tert-butyldimethylsilyl)oxy)icosa-6,13,17-trien-8,11-diynoate (19). Vinyl iodide 3 (51 mg, $0.14 \mathrm{mmol}, 1.0$ equiv) was dissolved in THF $(1.0 \mathrm{~mL})$, and the solution was cooled to $0{ }^{\circ} \mathrm{C}$ before $\mathrm{Pd}\left(\mathrm{PPh}_{3}\right)_{2} \mathrm{Cl}_{2}(5.0 \mathrm{mg}, 7.1$ $\mu \mathrm{mol}, 5.0 \mathrm{~mol} \%), \mathrm{CuI}(3.0 \mathrm{mg}, 15 \mu \mathrm{mol}, 11 \mathrm{~mol} \%)$, and $\mathrm{Et}_{3} \mathrm{~N}(52$ $\mathrm{mg}, 40 \mu \mathrm{L}, 0.28 \mathrm{mmol}, 2.0$ equiv) were added. Alkyne $18(56 \mathrm{mg}$, $0.17 \mathrm{mmol}, 1.2$ equiv) was dissolved in THF $(1.0 \mathrm{~mL})$ and added dropwise. The reaction mixture was allowed to slowly warm up to $\mathrm{rt}$ and stirred in the dark for $16 \mathrm{~h}$. After completion, the reaction mixture was filtrated through a plug of silica gel (15\% EtOAc in hexane) and concentrated in vacuo. The crude product thus obtained was purified by flash chromatography $\left(\mathrm{SiO}_{2}\right.$, gradient elution, $2.5-5 \% \mathrm{EtOAc}$ in hexane) to obtain product $19(62 \mathrm{mg}, 0.11 \mathrm{mmol}, 78 \%)$ as a clear oil. $R_{\mathrm{f}}\left(10 \%\right.$ EtOAc in hexane, visualized by UV and $\mathrm{KMnO}_{4}$ stain $)=$ 0.40; $[\alpha]_{\mathrm{D}}^{20}=+1.9(c 0.30$, benzene $) ;{ }^{1} \mathrm{H}$ NMR $\left(400 \mathrm{MHz}, \mathrm{CDCl}_{3}\right): \delta$ $6.12(\mathrm{dd}, J=15.9,5.2 \mathrm{~Hz}, 1 \mathrm{H}), 6.07(\mathrm{dd}, J=15.9,5.5 \mathrm{~Hz}, 1 \mathrm{H}), 5.69-$ $5.61(\mathrm{~m}, 2 \mathrm{H}), 5.50-5.42(\mathrm{~m}, 1 \mathrm{H}), 5.35-5.27(\mathrm{~m}, 1 \mathrm{H}), 4.19-4.13$ $(\mathrm{m}, 2 \mathrm{H}), 3.66(\mathrm{~s}, 3 \mathrm{H}), 3.42(\mathrm{t}, J=2.2 \mathrm{~Hz}, 2 \mathrm{H}), 2.30(\mathrm{t}, J=7.4 \mathrm{~Hz}$, $2 \mathrm{H}), 2.27-2.18(\mathrm{~m}, 2 \mathrm{H}), 2.02(\mathrm{pd}, J=7.2,1.5 \mathrm{~Hz}, 2 \mathrm{H}), 1.69-1.61$ $(\mathrm{m}, 2 \mathrm{H}), 1.52-1.47(\mathrm{~m}, 2 \mathrm{H}), 0.95(\mathrm{t}, J=7.5 \mathrm{~Hz}, 3 \mathrm{H}), 0.89(\mathrm{~s}, 18 \mathrm{H})$, $0.05(\mathrm{~s}, 3 \mathrm{H}), 0.04(\mathrm{~s}, 3 \mathrm{H}), 0.03(\mathrm{~s}, 3 \mathrm{H}), 0.02(\mathrm{~s}, 3 \mathrm{H}) ;{ }^{13} \mathrm{C}\left\{{ }^{1} \mathrm{H}\right\}$ NMR $\left(101 \mathrm{MHz}, \mathrm{CDCl}_{3}\right): \delta 174.1,146.2,146.1,134.1,124.2,109.0,108.6$, 83.8, 83.6, 79.2, 79.0, 72.6, 72.2, 51.6, 37.2, 36.0, 34.1, 26.0 (6C), 20.9, 20.5, 18.4, 18.3, 14.3, 11.3, -4.4, -4.5, -4.7, -4.8; HRESIMS $m / z: 595.3608[\mathrm{M}+\mathrm{Na}]^{+}\left(\right.$calcd for $\left.\mathrm{C}_{33} \mathrm{H}_{56} \mathrm{O}_{4} \mathrm{Si}_{2} \mathrm{Na}, 595.3609\right)$.

Methyl $(5 S, 6 E, 8 Z, 11 Z, 13 E, 15 S, 17 Z)-5,15$-Bis((tert-butyldimethylsilyl)oxy)icosa-6,8,11,13,17-pentaenoate (20). Diyne $19(10 \mathrm{mg}, 18 \mu \mathrm{mol}, 1.0$ equiv) was dissolved in a mixture of EtOAc/pyridine/1-octene (10:1:1, $0.3 \mathrm{~mL})$ under argon. Lindlar's catalyst $(7.0 \mathrm{mg})$ was added, and the flask was evacuated and refilled with hydrogen gas twice. After $1 \mathrm{~h}$, additional Lindlar's catalyst (7.0 $\mathrm{mg}$ ) was added. The reaction was stirred for another $4 \mathrm{~h}$ and filtrated through a short plug of silica gel (15\% EtOAc in hexane) and concentrated in vacuo. The crude product thus obtained was purified by flash chromatography $\left(\mathrm{SiO}_{2}, 1 \% \mathrm{EtOAc}\right.$ in hexane) to obtain product $20(7.0 \mathrm{mg}, 12 \mu \mathrm{mol}, 70 \%)$ as a pale yellow oil. $R_{\mathrm{f}}(10 \%$ EtOAc in hexane, visualized by $\mathrm{UV}$ and $\mathrm{KMnO}_{4}$ stain $)=0.38 ;[\alpha]_{\mathrm{D}}^{20}=$ +36.8 (c 0.25, benzene); ${ }^{1} \mathrm{H}$ NMR (400 MHz, $\left.\mathrm{CDCl}_{3}\right): \delta 6.49-6.40$ (m, 2H), 5.99 (app td, $J=10.9,2.0 \mathrm{~Hz}, 2 \mathrm{H}), 5.68(\mathrm{dd}, J=15.2,5.9$ $\mathrm{Hz}, 1 \mathrm{H}), 5.64(\mathrm{dd}, J=15.2,6.2 \mathrm{~Hz}, 1 \mathrm{H}), 5.49-5.32(\mathrm{~m}, 4 \mathrm{H}), 4.21-$ $4.16(\mathrm{~m}, 2 \mathrm{H}), 3.66(\mathrm{~s}, 3 \mathrm{H}), 3.05(\operatorname{app~t}, J=7.4 \mathrm{~Hz}, 2 \mathrm{H}), 2.32(\mathrm{t}, J=$ $7.3 \mathrm{~Hz}), 2.28-2.22(\mathrm{~m}, 2 \mathrm{H}), 2.03($ app p, $J=7.4 \mathrm{~Hz}, 2 \mathrm{H}), 1.72-1.64$ $(\mathrm{m}, 2 \mathrm{H}), 1.53-1.49(\mathrm{~m}, 2 \mathrm{H}), 0.95(\mathrm{t}, J=7.5 \mathrm{~Hz}, 3 \mathrm{H}), 0.91(\mathrm{~s}, 9 \mathrm{H})$, $0.90(\mathrm{~s}, 9 \mathrm{H}), 0.06(2 \times \mathrm{s}, 6 \mathrm{H}), 0.04(\mathrm{~s}, 3 \mathrm{H}), 0.03(\mathrm{~s}, 3 \mathrm{H}) ;{ }^{13} \mathrm{C}\left\{{ }^{1} \mathrm{H}\right\}$ NMR (101 MHz, $\left.\mathrm{CDCl}_{3}\right): \delta 174.2,137.3,137.2,133.7,129.3,129.1$, $128.7,128.6,124.8,124.6,124.3,73.2,72.9,51.6,37.8,36.5,34.2$, 26.6, 26.4 (6C), 20.9 (2C), 18.4 (2C), 14.4, -4.1, -4.3, -4.6, -4.6; HRESIMS $m / z: 599.3922[\mathrm{M}+\mathrm{Na}]^{+}$(calcd for $\mathrm{C}_{33} \mathrm{H}_{60} \mathrm{O}_{4} \mathrm{Si}_{2} \mathrm{Na}$, 599.3922).

Methyl (5S,6E,8Z,11Z,13E,15S,17Z)-5,15-Dihydroxyicosa$6,8,11,13,17$-pentaenoate (2). The bis-TBS-protected intermediate $20(10 \mathrm{mg}, 17 \mu \mathrm{mol}, 1.0$ equiv) was azeotroped with 2 -MeTHF (2 $\times 1 \mathrm{~mL}$ ) and then cooled to $0{ }^{\circ} \mathrm{C}$ before a solution of $\mathrm{AcCl}$ in dry $\mathrm{MeOH}(0.13 \mathrm{~mL}, 2.6 \mathrm{mmol}, 15 \mathrm{~mol} \%)$ was added (the solution was prepared just prior to use by adding freshly distilled $\mathrm{AcCl}(3.0 \mu \mathrm{L})$ to dry $\mathrm{MeOH}(2.0 \mathrm{~mL})$ under argon). The reaction mixture was stirred for $4 \mathrm{~h}$ at $0{ }^{\circ} \mathrm{C}$. The reaction mixture was diluted with $\mathrm{CH}_{2} \mathrm{Cl}_{2}(0.3$ $\mathrm{mL})$ prior to neutralization with a $10 \%$ aq. solution of $\mathrm{NaHCO}_{3}(20$ $\mu \mathrm{L})$ and washed with $\mathrm{H}_{2} \mathrm{O}(0.2 \mathrm{~mL})$. The organic phase was dried $\left(\mathrm{Na}_{2} \mathrm{SO}_{4}\right)$, filtrated, and concentrated in vacuo. The crude product thus obtained was purified by flash chromatography $\left(\mathrm{SiO}_{2}, 40 \%\right.$ EtOAc in hexane) to afford the RvE4 methyl ester (2, $4.0 \mathrm{mg}, 12$ $\mu \mathrm{mol}, 66 \%)$ as a clear oil. The chemical purity $(>97 \%)$ was determined by HPLC analysis (Eclipse XDB-C18, $\mathrm{MeOH} / \mathrm{H}_{2} \mathrm{O}$ $76: 24,1.0 \mathrm{~mL} / \mathrm{min}): t_{\mathrm{r}}$ (minor) $=7.88,10.89$ and $11.69 \mathrm{~min}$, and $t_{\mathrm{r}}($ major $)=9.37 \mathrm{~min} . R_{\mathrm{f}}(40 \%$ EtOAc in hexane, visualized by UV and $\mathrm{KMnO}_{4}$ stain $)=0.17 ;[\alpha]_{\mathrm{D}}^{20}=+8.4(c 0.5, \mathrm{MeOH}) ; \mathrm{UV}-\mathrm{Vis}$ $(\mathrm{MeOH}) \lambda_{\max } 242 \mathrm{~nm}(\log \varepsilon=4.64) ;{ }^{1} \mathrm{H}$ NMR $(400 \mathrm{MHz}, \mathrm{MeOD}):$ $\delta 6.61-6.54(\mathrm{~m}, 2 \mathrm{H}), 6.01(\mathrm{td}, J=11.0,4.9 \mathrm{~Hz}, 2 \mathrm{H}), 5.69$ (app ddd, $J$ $=15.5,9.2,6.5 \mathrm{~Hz}, 2 \mathrm{H}) 5.51-5.34(\mathrm{~m}, 4 \mathrm{H}), 4.13(\mathrm{p}, J=6.8 \mathrm{~Hz}, 2 \mathrm{H})$, $3.66(\mathrm{~s}, 3 \mathrm{H}), 3.10(\mathrm{tt}, J=7.5,1.7 \mathrm{~Hz}, 2 \mathrm{H}), 2.36(\mathrm{t}, J=7.2 \mathrm{~Hz}, 2 \mathrm{H})$, $2.35-2.27(\mathrm{~m}, 2 \mathrm{H}), 2.06$ (app dp, $J=7.4,0.8 \mathrm{~Hz}, 2 \mathrm{H}), 1.73-1.63(\mathrm{~m}$, $2 \mathrm{H}), 1.57-1.51(\mathrm{~m}, 2 \mathrm{H}), 0.96(\mathrm{t}, J=7.5 \mathrm{~Hz}, 3 \mathrm{H}) ;{ }^{13} \mathrm{C}\left\{{ }^{1} \mathrm{H}\right\} \mathrm{NMR}$ (101 MHz, MeOD): $\delta$ 175.8, 137.8, 137.5, 134.6, 130.3, 130.2, 129.6 (2C), 126.3 (2C), 125.5, 73.2, 72.8, 52.0, 37.6, 36.3, 34.6, 27.4, 22.1, 21.7, 14.5; HRESIMS $m / z$ : $371.2192[\mathrm{M}+\mathrm{Na}]^{+}$(calcd for $\mathrm{C}_{21} \mathrm{H}_{32} \mathrm{O}_{4} \mathrm{Na}$, 371.2193).

LC-MS/MS MRM Matching Experiments. Following a literature procedure, ${ }^{36}$ a solution of RvE4 methyl ester $(2,5.0 \mu \mathrm{g}$, $14 \mathrm{nmol}$ ) in $\mathrm{MeOH}$ was concentrated under a gentle stream of nitrogen gas, dissolved in THF $(500 \mu \mathrm{L})$, and cooled to $-78{ }^{\circ} \mathrm{C}$. To the resulting solution was added $1 \mathrm{M} \mathrm{LiOH}(50 \mu \mathrm{L}, 50 \mu \mathrm{mol})$ and distilled water (one drop, $\sim 20 \mu \mathrm{L}$ ) and the reaction mixture was stirred in a $4{ }^{\circ} \mathrm{C}$ cold room for $24 \mathrm{~h}$. The reaction mixture was then concentrated under a gentle stream of nitrogen gas and reconstituted with $\mathrm{MeOH}(500 \mu \mathrm{L})$. The identity of the compound was verified by $\mathrm{UV}-\mathrm{Vis}$ and LC-MS/MS. The chemical yield of the RvE4 free acid $\mathbf{1}$ was $69 \%(3.3 \mu \mathrm{g}, 9.9 \mathrm{nmol})$ post saponification (based on UV-Vis) and was determined to be $>95 \%$ pure by targeted MRM LC-MS/ MS. The physical properties of synthetic RvE4 (1) and biogenic RvE4 (1) were analyzed on a QTRAP 5500 mass spectrometer (Sciex, Framingham, MA, USA) equipped with a LC20AD UFLC (Shimadzu, Tokyo, Japan) with a Poroshell EC-C18 column (100 $\mathrm{mm} \times 4.6 \mathrm{~mm} \times 2.7 \mu \mathrm{m}$; Agilent Technologies, Santa Clara, CA, USA) kept at $50{ }^{\circ} \mathrm{C}$. RvE4 (1) was monitored by targeted multiple reaction monitoring $(\mathrm{m} / z 333>115)$ and enhanced product ion mode in negative polarity. $\operatorname{RvE} 4$ (1) was eluted at a flow rate of 0.5 $\mathrm{mL} / \mathrm{min}$ with a gradient of LC-MS grade methanol/water/acetic acid from 50/50/0.01 v/v/v to 98/2/0.01 v/v/v. Data were acquired and analyzed with Analyst version 1.6.2 (Sciex). ${ }^{8}$

\section{ASSOCIATED CONTENT}

\section{Supporting Information}

The Supporting Information is available free of charge at https://pubs.acs.org/doi/10.1021/acs.joc.0c02913.

${ }^{1} \mathrm{H}-,{ }^{13} \mathrm{C} \mathrm{NMR}$, and UV-Vis data of RvE4 methyl ester (2) and all synthetic intermediates (PDF) 


\section{AUTHOR INFORMATION}

\section{Corresponding Author}

Marius Aursnes - Department of Pharmacy, Section for Pharmaceutical Chemistry, University of Oslo, 0316 Oslo, Norway; 이이.org/0000-0002-9960-0254;

Email: marius.aursnes@farmasi.uio.no

\section{Authors}

Amalie Føreid Reinertsen - Department of Pharmacy, Section for Pharmaceutical Chemistry, University of Oslo, 0316 Oslo, Norway; (1) orcid.org/0000-0003-0133-7986

Karoline Gangestad Primdahl - Department of Pharmacy, Section for Pharmaceutical Chemistry, University of Oslo, 0316 Oslo, Norway; o orcid.org/0000-0001-7060-5900

Ashley Elizabeth Shay - Center for Experimental Therapeutics and Reperfusion Injury, Department of Anesthesiology, Perioperative and Pain Medicine, Hale Building for Transformative Medicine, Brigham and Women's Hospital and Harvard Medical School, Boston, Massachusetts 02115, United States

Charles Nicholas Serhan - Center for Experimental Therapeutics and Reperfusion Injury, Department of Anesthesiology, Perioperative and Pain Medicine, Hale Building for Transformative Medicine, Brigham and Women's Hospital and Harvard Medical School, Boston, Massachusetts 02115, United States; (1) orcid.org/00000003-4627-8545

Trond Vidar Hansen - Department of Pharmacy, Section for Pharmaceutical Chemistry, University of Oslo, 0316 Oslo, Norway; ○ orcid.org/0000-0001-5239-9920

Complete contact information is available at: https://pubs.acs.org/10.1021/acs.joc.0c02913

\section{Author Contributions}

${ }^{\S}$ A.F.R., K.G.P., and M.A. contributed equally.

\section{Notes}

The authors declare no competing financial interest.

\section{ACKNOWLEDGMENTS}

The scholarship to A.F.R. by the Department of Pharmacy is gratefully acknowledged. M.A. gratefully acknowledges the Research Council of Norway (RCN) for a grant (FRINATEK, 262901). This work was partly supported by the Research Council of Norway through the Norwegian NMR Package in 1994 and partly supported by the Research Council of Norway through the Norwegian NMR Platform, NNP (226244/F50). C.N.S. contributions are supported by NIH grant R01GM038765 (USA) and NIH Program Project P01GM095467 (USA).

\section{REFERENCES}

(1) (a) Serhan, C. N. Pro-resolving lipid mediators are leads for resolution physiology. Nature 2014, 510, 92-101. (b) Tabas, I.; Glass, C. K. Anti-Inflammatory Therapy in Chronic Disease: Challenges and Opportunities. Science 2013, 339, 166-172.

(2) Serhan, C. N.; Petasis, N. A. Resolvins and Protectins in Inflammation-Resolution. Chem. Rev. 2011, 111, 5922-5943 and references cited therein.

(3) Serhan, C. N.; Levy, B. D. Resolvins in inflammation: emergence of the pro-resolving superfamily of mediators. J. Clin. Invest. 2018, $128,2657-2669$.

(4) (a) Serhan, C. N.; Clish, C. B.; Brannon, J.; Colgan, S. P.; Chiang, N.; Gronert, K. Novel functional sets of lipid-derived mediators with antiinflammatory actions generated from omega-3 fatty acids via cyclooxygenase 2-nonsteroidal antiinflammatory drugs and transcellular processing. J. Exp. Med. 2000, 192, 1197-1204. (b) Serhan, C. N.; Hong, S.; Gronert, K.; Colgan, S. P.; Devchand, P. R.; Mirick, G.; Moussignac, R.-L. Resolvins: a family of bioactive products of omega-3 fatty acid transformation circuits initiated by aspirin treatment that counter proinflammation signals. J. Exp. Med. 2002, 196, 1025-1037.

(5) Dalli, J.; Serhan, C. N. Identification and structure elucidation of the pro-resolving mediators provides novel leads for resolution pharmacology. Br. J. Pharmacol. 2019, 176, 1024-1037.

(6) (a) Shimamura, K.; Matsuda, M.; Miyamoto, Y.; Yoshimoto, R.; Seo, T.; Tokita, S. Identification of a stable chemerin analog with potent activity toward ChemR23. Peptides 2009, 30, 1529-1538. (b) Arita, M.; Oh, S. F.; Chonan, T.; Hong, S.; Elangovan, S.; Sun, Y.P.; Uddin, J.; Petasis, N. A.; Serhan, C. N. Metabolic Inactivation of Resolvin E1 and Stabilization of Its Anti-inflammatory Actions. J. Biol. Chem. 2006, 281, 22847-22854. (c) Hesselink, J. M. K.; Chiosi, F.; Costagliola, C. Resolvins and aliamides: lipid autacoids in ophthalmology - what promise do they hold? Drug Des., Dev. Ther. 2016, 10, 3133-3141. (d) Murakami, Y.; Fukuda, H.; Muromoto, R.; Hirashima, K.; Ishimura, K.; Fuijwara, K.; Ishihara, J.; Matsuda, T.; Watanabe, M.; Shuto, S. Design and Synthesis of Benzene Congeners of Resolvin E2, a Proresolving Lipid Mediator, as Its Stable Equivalents. ACS Med. Chem. Lett. 2020, 11, 479-484.

(7) (a) Fullerton, J. N.; Gilroy, D. W. Resolution of inflammation: a new therapeutic frontier. Nat. Rev. Drug Discovery 2016, 15, 551-567. (b) Dalli, J. Does promoting resolution instead of inhibiting inflammation represent the new paradigm in treating infections? Mol. Aspects Med. 2017, 58, 12-20.

(8) Norris, P. C.; Libreros, S.; Serhan, C. N. Resolution metabolomes activated by hypoxic environment. Sci. Adv. 2019, 5 , No. eaax 4895 .

(9) (a) Isobe, Y.; Arita, M.; Iwamoto, R.; Urabe, D.; Todoroki, H.; Masuda, K.; Inoue, M.; Arai, H. Stereochemical assignment and antiinflammatory properties of the omega-3 lipid mediator resolvin E3. $J$. Biochem. 2013, 153, 355-360. (b) Oh, S. F.; Pillai, P. S.; Recchiuti, A.; Yang, R.; Serhan, C. N. Pro-resolving actions and stereoselective biosynthesis of $18 \mathrm{~S}$ E-series resolvins in human leukocytes and murine inflammation. J. Clin. Invest. 2011, 121, 569-581.

(10) Recent total synthesis of E-series resolvins: (a) Fukuda, H.; Ikeda, H.; Muromoto, R.; Hirashima, K.; Ishimura, K.; Fujiwara, K.; Aoki-Saito, H.; Hisada, T.; Watanabe, M.; Ishihara, J.; Matsuda, T.; Shuto, S. Synthesis of Resolvin E3, a Proresolving Lipid Mediator, and Its Deoxy Derivatives: Identification of 18-Deoxy-resolvin E3 as a Potent Anti-Inflammatory Agent. J. Org. Chem. 2020, 85, 1419014200. (b) Urbitsch, F.; Elbert, B. L.; Llaveria, J.; Streatfeild, P. E.; Anderson, E. A. A Modular, Enantioselective Synthesis of Resolvins D3, E1, and Hybrids. Org. Lett. 2020, 22, 1510-1515. (c) Saito, S.; Nanba, Y.; Morita, M.; Kobayashi, Y. The Hudrlik-Peterson Reaction of Secondary cis-TMS-Epoxy Alcohols and its Application to the Synthesis of the Fatty Acid Intermediates. Synlett 2019, 30, 10851089. (d) Nesman, J. I.; Tungen, J. E.; Vik, A.; Hansen, T. V. Stereoselective synthesis of the specialized pro-resolving and antiinflammatory mediator resolvin E1. Tetrahedron 2020, 76, 130821.

(11) For a recent review on total synthesis and biological evaluations of E-series resolvins, see Vik, A.; Hansen, T. V. Stereoselective syntheses and biological activities of E-series resolvins. Org. Biomol. Chem. 2021 DOI: 10.1039/D0OB02218G.

(12) Sonogashira, K.; Tohda, Y.; Hagihara, N.; Sonogashira, K.; Tohda, Y.; Hagihara, N. A convenient synthesis of acetylenes: catalytic substitutions of acetylenic hydrogen with bromoalkenes, iodoarenes and bromopyridines. Tetrahedron Lett. 1975, 16, 44674470.

(13) (a) Gotoh, H.; Hayashi, Y. Diphenylprolinol silyl ether as a catalyst in an asymmetric, catalytic and direct $\alpha$-benzoyloxylation of aldehydes. Chem. Commun. 2009, 3083-3085. (b) Hayashi, Y.; Umekubo, M.; Hirama, T. Prolinate Salts as Catalysts for $\alpha$ Aminoxylation of Aldehyde and Associated Mechanistic Insights. 
Org. Lett 2017, 19, 4155-4158. (c) Carpenter, J.; Northrup, A. B.; Chung, d.; Wiener, J. J. M.; Kim, S.-G.; MacMillan, D. W. C. Total Synthesis and Structural Revision of Callipeltoside C. Angew. Chem., Int. Ed. 2008, 47, 3568-3572. (d) Brown, S. P.; Brochu, M. P.; Sinz, C. J.; MacMillan, D. W. C. The Direct and Enantioselective Organocatalytic $\alpha$-Oxidation of Aldehydes. J. Am. Chem. Soc. 2003, 125, 10808-10809. (e) Donohoe, T. J.; Lindsay-Scott, P. J.; Parker, J. S.; Callens, C. K. A. New modes for the Osmium-Catalysed Oxidative Cyclization. Org. Lett. 2010, 12, 1060-1063.

(14) Takai, K.; Nitta, K.; Utimoto, K. Simple and selective method for $\mathrm{RCHO} \rightarrow(E)-\mathrm{RCH}=\mathrm{CHX}$ conversion by means of a $\mathrm{CHX}_{3}-$ $\mathrm{CrCl}_{2}$ system. J. Am. Chem. Soc. 1986, 108, 7408-7410.

(15) Dess, D. B.; Martin, J. C. Readily accessible 12-I-5 oxidant for the conversion of primary and secondary alcohols to aldehydes and ketones. J. Org. Chem. 1983, 48, 4155-4156.

(16) Tungen, J. E.; Gerstmann, L.; Vik, A.; de Mateis, R.; Colas, R. A.; Dalli, J.; Chiang, N.; Serhan, C. N.; Kalesse, M.; Hansen, T. V. Resolving Inflammation: Synthesis, Configurational Assignment, and Biological Evaluation of RvD1 $1_{\mathrm{n}-3}$ DPA . Chem. Eur. J. 2019, 25, 14761480.

(17) Hayashi, Y. Pot economy and one-pot synthesis. Chem. Sci. 2016, 7, 866-880.

(18) Hoover, J. M.; Stahl, S. S. Highly Practical Copper(I)/TEMPO Catalyst System for Chemoselective Aerobic Oxidation of Primary Alcohols. J. Am. Chem. Soc. 2011, 133, 16901-16910.

(19) Frantz, D. E.; Fässler, R.; Carreira, E. M. Facile Enantioselective Synthesis of Propargylic Alcohols by Direct Addition of Terminal Alkynes to Aldehydes. J. Am. Chem. Soc. 2000, 122, 1806-1807.

(20) Boyall, D.; Lopez, F.; Sasaki, H.; Frantz, D.; Carreira, E. M. Enantioselective Addition of 2-Methyl-3-butyn-2-ol to Aldehydes: Preparation of 3-Hydroxy-1-butynes. Org. Lett. 2000, 26, 4233-4236.

(21) Birkofer, L.; Ritter, A.; Uhlenbrauck, H. Siliconorganic compounds. XXI. Substitution and addition reactions with silylated acetylenes. Chem. Ber. 1963, 96, 3280-3288.

(22) Midland, M. M.; McDowell, D. C.; Hatch, R. L.; Tramontano, A. Reduction of $\alpha, \beta$-acetylenic ketones with B-3-pinanyl-9borabicyclo[3.3.1]nonane. High asymmetric induction in aliphatic systems. J. Am. Chem. Soc. 1980, 102, 867-869.

(23) Schmidt, H. M.; Arens, J. F. Cleavage of the carbon-silicon bond in 1-alkynylsilanes by silver nitrate: Protection of a terminal triple bond in hydrogenation reactions with the trimethylsilyl group. Rec. Trav. Chim. Pays-Bas 1967, 86, 1138-1142.

(24) (a) Aursnes, M.; Tungen, J. E.; Vik, A.; Dalli, J.; Hansen, T. V. Stereoselective synthesis of protectin D1: a potent anti-inflammatory and proresolving lipid mediator. Org. Biomol. Chem. 2014, 12, 432437. (b) Aursnes, M.; Tungen, J. E.; Vik, A.; Colas, R.; Cheng, C. C.; Dalli, J.; Serhan, C. N.; Hansen, T. V. Total Synthesis of the Lipid Mediator PD $1_{\mathrm{n}-3 \mathrm{DPA}}$ : Configurational Assignments and Anti-inflammatory and Pro-resolving Actions. J. Nat. Prod. 2014, 77, 910-916. (c) Tungen, J. E.; Aursnes, M.; Hansen, T. V. Stereoselective synthesis of maresin 1. Tetrahedron Lett. 2015, 56, 1843-1846. (d) Tungen, J. E.; Aursnes, M.; Dalli, J.; Arnardottir, H.; Serhan, C. N.; Hansen, T. V. Total Synthesis of the Anti-inflammatory and Proresolving Lipid Mediator MaR $1_{n-3}$ DPA Utilizing an $\mathrm{sp}^{3}-\mathrm{sp}^{3}$ Negishi Cross-Coupling Reaction. Chem. Eur. J. 2014, 20, 14575-14578.

(25) Khan, A. T.; Mondal, E. A Highly Efficient and Useful Synthetic Protocol for the Cleavage of tert-Butyldimethylsilyl (TBS) Ethers Using a Catalytic Amount of Acetyl Chloride in Dry Methanol. Synlett 2003, 5, 694-698.

(26) Hansen, T. V.; Dalli, J.; Serhan, C. N. The novel lipid mediator PD $1_{n-3}$ DPA: An overview of the structural elucidation, synthesis, biosynthesis and bioactions. Prostaglandins Other Lipid Mediat. 2017, 133, 103-110.

(27) (a) MacMillan, D. W. C. The advent and development of organocatalysis. Nature 2008, 455, 304-308. (b) Waser, M. Asymmetric Organocatalysis in Natural Product Syntheses; Springer: Wien, 2012. (c) Xiang, S.; Tan, B. Advances in asymmetric organocatalysis over the last 10 years. Nat. Commun. 2020, 11, 3786.
(28) Corey, E. J.; Shirahama, H.; Yamamoto, H.; Terashima, S.; Venkateswarlu, A.; Schaaf, T. K. Stereospecific Total Synthesis of Prostaglandins $\mathrm{E}_{3}$ and $\mathrm{F}_{3}$. J. Am. Chem. Soc. 1971, 93, 1490-1491.

(29) Reid, B. T.; Mailyan, A. K.; Zakarian, A. Total Synthesis of (+)Guadinomic Acid via Hydroxyl-Directed Guanidylation. J. Org. Chem. 2018, 83, 9492-9496.

(30) Gannett, P. M.; Nagel, D. L.; Reilly, P. J.; Lawson, T.; Sharpe, J.; Toth, B. The Capsaicinoids: Their Separation, Synthesis, and Mutagenicity. J. Org. Chem. 1988, 53, 1064-1071.

(31) Götz, K.; Liermann, J. C.; Thines, E.; Anke, H.; Opatz, T. Structure elucidation of hypocreolide A by enantioselective total synthesis. Org. Biomol. Chem. 2010, 8, 2123-2130.

(32) Yang, P.; Zhong, J.; Ji, K.; Yin, J.; Li, S.; Wei, S.; Zhou, Y.; Wang, L.; Wang, M.; Bian, Q. Catalytic asymmetric synthesis of Leukotriene $\mathrm{B}_{4}$. Tetrahedron: Asymmetry 2017, 28, 1596-1601.

(33) Treilhou, M.; Fauve, A.; Pougny, J.-R.; Prom, J.-C.; Veshambre, $\mathrm{H}$. Use of Biological Catalysts for the Preparation of Chiral Molecules. 8. Preparation of Propargylic Alcohols. Application in the Total Synthesis of Leukotriene $B_{4}$. J. Org. Chem. 1992, 57, 3203-3208.

(34) Primdahl, K. G.; Tungen, J. E.; Aursnes, M.; Hansen, T. V.; Vik, A. An efficient total synthesis of leukotriene B4. Org. Biomol. Chem. 2015, 13, 5412-5417.

(35) Boer, R. E.; Gimnez-Bastida, J. A.; Boutaud, O.; Jana, S.; Schneider, C.; Sulikowski, G. A. Total Synthesis and Biological Activity of the Arachidonic Acid Metabolite Hemiketal $\mathrm{E}_{2}$. Org. Lett. 2018, 20, 4020-4022.

(36) Chang, M.; Rao, M. K.; Reddanna, P.; Li, C. H.; Tu, C.-P. D.; Corey, E. J.; Reddy, C. C. I. Specificity of the glutathione $S$ transferases in the conversion of leukotriene $\mathrm{A}_{4}$ to leukotriene $\mathrm{C}_{4}$. Arch. Biochem. Biophys. 1987, 259, 536-547. 